\title{
Basic geochemical characteristics of lacustrine rocks in the Neogene Kağızman-Tuzluca Basin, Northeastern Turkey
}

\author{
Turhan Ayyıldız $^{1}$ Baki Varol $^{1} \cdot$ Zehra Karakaş $^{1} \cdot$ Koray Sözeri $^{2}$
}

Received: 20 June 2017 / Accepted: 4 July 2018 / Published online: 27 July 2018

(c) The Author(s) 2018

\begin{abstract}
The Neogene Kağızman-Tuzluca Basin is located in the NE Anatolia and extends eastward into Armenia Oktemberian Basin. The Halıkışlak (Late Oligocene), Turabi and Tuzluca formations (Lower-Middle Miocene) are time equivalents of the organic-rich Oligo-Miocene Maikop Series in the Caspian region. However, depositional conditions within the KBT are appreciably different and source rocks are not as richer as it. The Halıkışlak Formation has little source rock potentials, with very low values of TOC $(0.04-0.25 \%)$, HI (14-90 mg HC/TOC) and genetic potential-GP (i.e. Rock-Eval $S_{1}+S_{2}=0.05$ to $0.22 \mathrm{mg} \mathrm{HC} / \mathrm{g}$ rock). Although a peat facies sample has a relatively high TOC $(6.78 \%), T_{\max }$ of $428{ }^{\circ} \mathrm{C}$, HI values are very low (45 mg HC/TOC). TOC and GP values for the Tuzluca Formation are between 0.06 and $0.39 \mathrm{wt} \%$, and $0.16-1.51 \mathrm{mg}$ $\mathrm{HC} / \mathrm{g}$ rock, respectively. Some levels of the Turabi Formation have TOC contents up to $6.14 \mathrm{wt} \%$; however, mainly $T_{\max }$ values are low $435^{\circ} \mathrm{C}$, and $\mathrm{HI}$ range from 25 to $54 \mathrm{mg} \mathrm{HC} / \mathrm{TOC}$. The extract of one low-maturity Turabi sample possesses biomarker distributions of an immature rock. Low relative abundance of tricyclic terpane and dominant C29 $\alpha \alpha \alpha(20 \mathrm{R})$ are in accordance with the immature source rock. Some samples collected from the outcrops nearby Pliocene/Pleistocene lava series show localized maturation stage. We suggest that the Oligocene to Middle Miocene units could be more studied beneath the volcanic plateau.
\end{abstract}

Keywords Kağızman-Tuzluca basin · Turabi Formation · Intermountain basin · Oligo-Miocene units · Kömürlü Formation $\cdot$ Lacustrine source rock

\section{Introduction}

In many parts of the world, organic-rich lacustrine sediments provide potential sources for the oil and/or gas (e.g., Paradox, Michigan and Uinta basins in USA; Tarim, Songliao, Junggar and Bohai Bay basins in China; Campos basin Brazil, Gongola Basin in Nigeria; Dong Ho and Song Hong basins, Vietnam). This depositional environment has received considerable attention in recent years for petroleum (e.g., Carroll and Bohacs 2001; Obaje et al. 2004; Petersen et al. 2005; Tian et al. 2014; Gao et al. 2016). Turkey has numerous lacustrine basins, mostly formed during the Paleogene and Neogene periods (e.g., Şengör 1987; Purvis

Turhan Ayyıldiz

ayyildiz@eng.ankara.edu.tr

1 Department of Geological Engineering, Engineering Faculty, Gölbaşı Campus, Ankara University, 06830 Ankara, Turkey

2 General Directorate of Mineral Research and Exploration, 06800 Ankara, Turkey and Robertson 2005a, b; Çiftçi and Bozkurt 2010). These basins have been widely explored for raw mineral materials such as trona, thenardite, (Central Anatolian) and borate (Western Anatolian) (e.g., İnci 1991; Helvacı and Orti 1998; García-Veigas and Helvaci 2013). Petroleum exploration has been largely limited to the Alaşehir (Gediz) graben (Ediger et al. 1996). The Kömürlü Formation of Ardahan Basin at the northwestern part of the study area (Uğur 2000; Sancay 2005) has been examined for unconventional properties (Aydemir 2010). However; the eastern Anatolian lacustrine basins have not been a target for the petroleum exploration. The Neogene Kağızman-Tuzluca Basin (KTB) is one of the main Upper Oligocene to Miocene lacustrine basins, located in the Eastern Anatolian plateau (Fig. 1) that formed as part of a Himalayan-type orogenic system (Dhont et al. 2006; Göğüş and Psyklywec 2008; Sharkov et al. 2015). Studies of the geology and tectonics of the KTB are reported in some workers (Eşder 1967; Yılmaz and Şener 1984; Şaroğlu and Yilmaz 1986; Sancay 2005; Y1lmaz 2007; Varol et al. 2016). Petroleum and geothermal energy assessments have been 


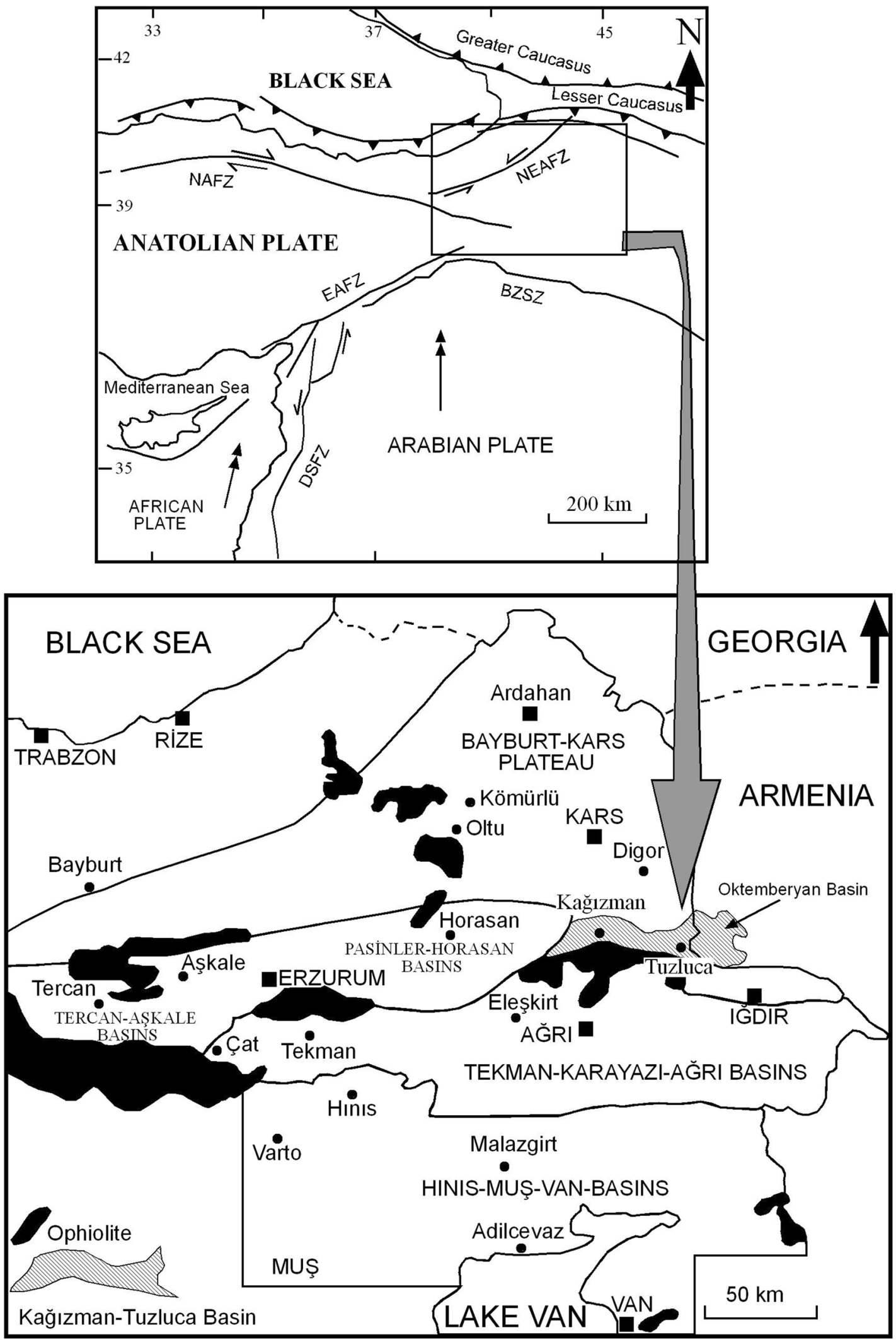

Fig. 1 Location map of the Eastern Anatolian subbasins ( DSFZ Dead Sea Fault Zone, NAFZ North Anatolian Fault Zone, NEAFZ Northeast Anatolian Fault Zone, EAFZ East Anatolian Fault Zone, BZSZ Bitlis-Zagros Suture Zone (modified from Bozkurt 2001; Şahintürk et al. 1998) 
performed by a few workers (Şenalp 1966; Şenalp 1969a, b; Tanriverdi 1971; Varol et al. 2009; Ayyıldız et al. 2011). However, there are no published data about the source rocks and their petroleum potential. This study is the first comprehensive investigation with analytical data based on sedimentology and basin evolution, and organic geochemistry of prominent lacustrine source rocks in the basin.

\section{General petroleum assessment of the Kağızman-Tuzluca and nearby basins}

The KTB is one of the important Tertiary basins in the eastern Anatolia. The basin is $40 \mathrm{~km}$ long and $10-15 \mathrm{~km}$ wide on average, extending eastwards across the river Aras (Araxes) into western Armenia where it is referred as Arexes and Oktemberian or Hoktemberian Basin (Balian 1969; Karakhanian et al. 2002; Hässig et al. 2013; Klett 2016) (Fig. 2). Although the basin consists of very thick (more than $2500 \mathrm{~m}$ ), overfilled and underfilled lacustrine deposits, these sediments have not drawn much attention of petroleum explorations. Early exploration activities in the KTB started in the 1960s, commenced by MTA (General Directorate of Mineral Research and Exploration). MTA drilled two exploration wells about $2500 \mathrm{~m}$ deep to the NE of Tuzluca. Commercial volumes of petroleum were not discovered (Eşder 1968a, b, c). Only methane was reported to occur at different levels in the Tuzluca-1 well (Şenalp 1969a, b). Log determinations and preliminary reports concerning these wells are sealed; and samples are not currently available. Subsequently, we could not perform organic geochemical analysis on the cutting samples from these wells.

Oil shows from Oligocene units were reported in the Armenian (Oktemberian) Basin that was located in the NE extension of the KTB. However, locally generated hydrocarbon extracts suggest that these sediments are immature and hydrocarbon must have been generated at depth from more mature sediments beneath the ophiolite (Papworth and Aghabalyan 2002a, b). Transeuro Energy Corp., (2007) discovered the active Oligocene-Eocene petroleum system in the Oktemberian Basin. Fifteen wells was drilled in the basin and natural gas was tested from the well Oktemberian-13E over a 6-month period (Papworth 2002; Papworth and Aghabalyan 2002a, b). Petroleum exploration activities have been carried out by the SE Armenia Project Consortium. A 1995 study concluded that total in-place resources in the Oktemberian Basin may comprise 70 million bbl of oil (estimated 14 million bbl recoverable) in the Garni-Shorakhpur area, east of Yerevan (part of the Central Depression), together with 144 bcf gas in-place (110 bcf recoverable) (Papworth and Aghabalyan 2002a, b). These productive series (Oktemberian or Hoktemberian Suite-Lower Sand-Clay and Upper
Multicolored Suite) are time equivalent of Halıkışlak and Turabi formations in the KTB (Fig. 3).

The Caspian region situated to the north of the study area has been studied in detail. The accumulation of organicrich sediments occurred during an episode of isolation of the Paratethys Sea during Alpine-Himalayan collision (Golonka 2007), has made the south Caspian region one of the most productive oil-producing regions in the world (e.g., Guliyev et al. 2001; Feyzullayev et al. 2001; Bechtel et al. 2013). Therefore, there are numerous publications dealing with organic matter maturity and source rock potential of the Caspian basins, particularly Maikop series (e.g., Lerche et al. 1997; İnan et al. 1998; Guliyev et al. 2001; Feyzullayev et al. 2001; Bechtel et al. 2013).

\section{Geological setting and stratigraphy}

The studied basin is surrounded by the Neogene Pasinler-Horasan Basin to the west, the Tekman-Karayazı-Ağrı Basin to the south, and the Miocene and younger volcanics of the Bayburt-Kars volcanic plateau to the north (Fig. 1). Previous studies based on the basin-fill deposits suggested that two different basin models are consistent with the tectonic constraints as a pull-apart basin (Şaroğlu and Yilmaz 1986; Koçyiğit et al. 2001; Varol et al. 2009) and intermountain basin (Şen et al. 2011; Ayy1ldız et al. 2012). Dhont and Chorowicz (2006) suggest that KTB does not have a rhombshaped geometry and there are no dog-leg relays along the Tuzluca fault that would allow the opening of such a transtensional basin as pull-apart structure. The KTB was formed in the compressional zone extending across Azerbaijan, Iran and Armenia, resulting from the convergence of the Afro-Arabian and Eurasian plates (Adamia et al. 2011).

Şen et al. (2011) established a new Cenozoic stratigraphic scheme on the basis of recent discoveries of mammalian fossils, revealing sedimentologic aspects of marine-terrestrial mixed deposits in the basin in the range from Eocene (?)/Late Oligocene to Late Miocene age. This stratigraphic scheme nearly consisted of the contemporaneous deposits of the Oktemberian Basin in Armenia (Papworth and Aghabalyan 2002a, b). The basement rocks and basin-fill units are stratigraphically described in the below.

\section{Basement rocks}

The basement rocks in the basin consist of serpentines, volcanics and marbles that are only exposed along the southern margin of the basin (Fig. 2) (Şahintürk and Kasar 1979; Şahintürk et al. 1998).

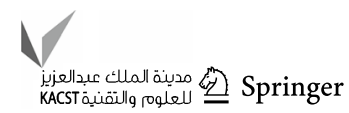




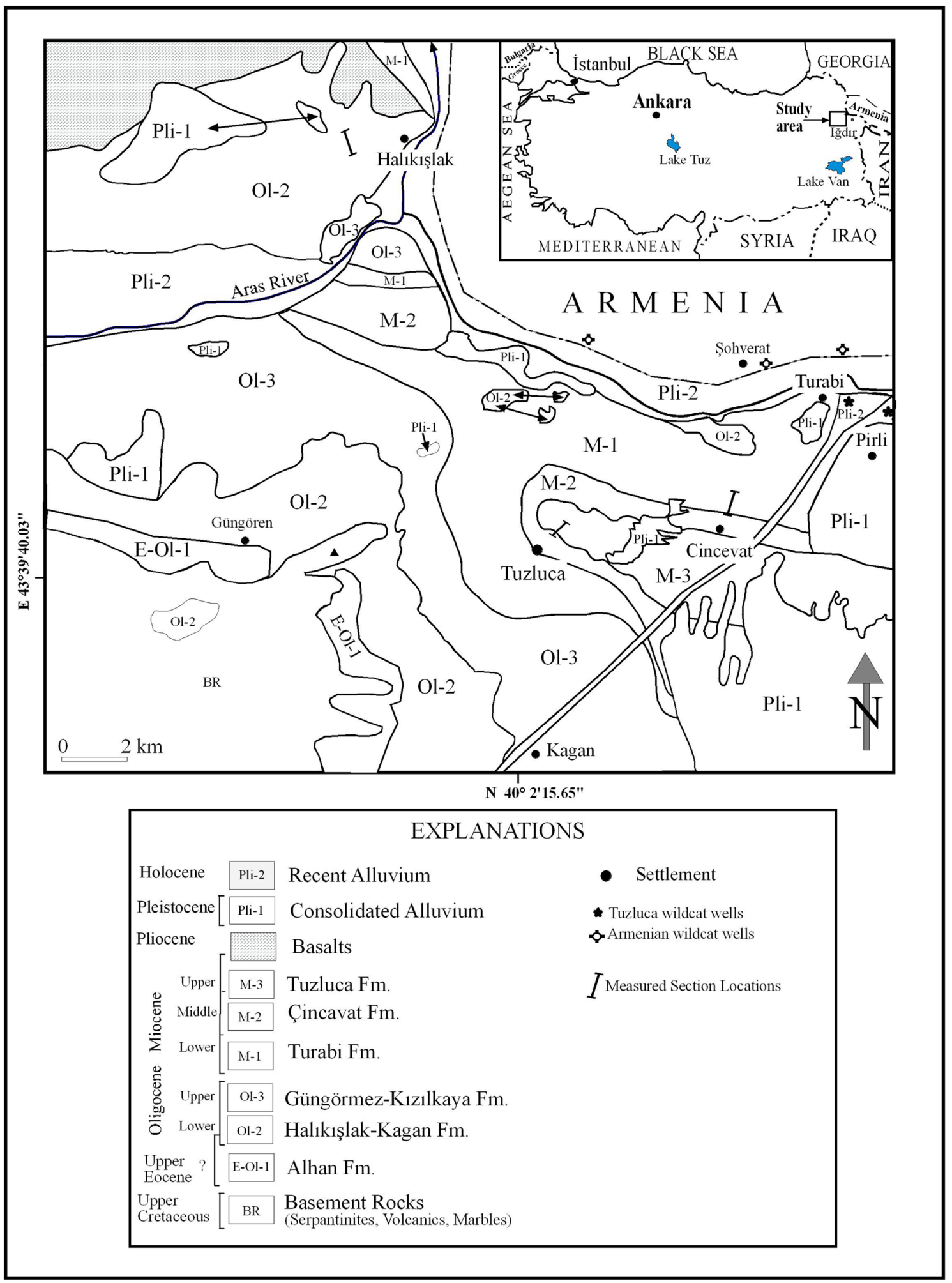

Fig. 2 Geological map of the Tuzluca area (revised from Şen et al. 2011; Varol et al. 2016) 


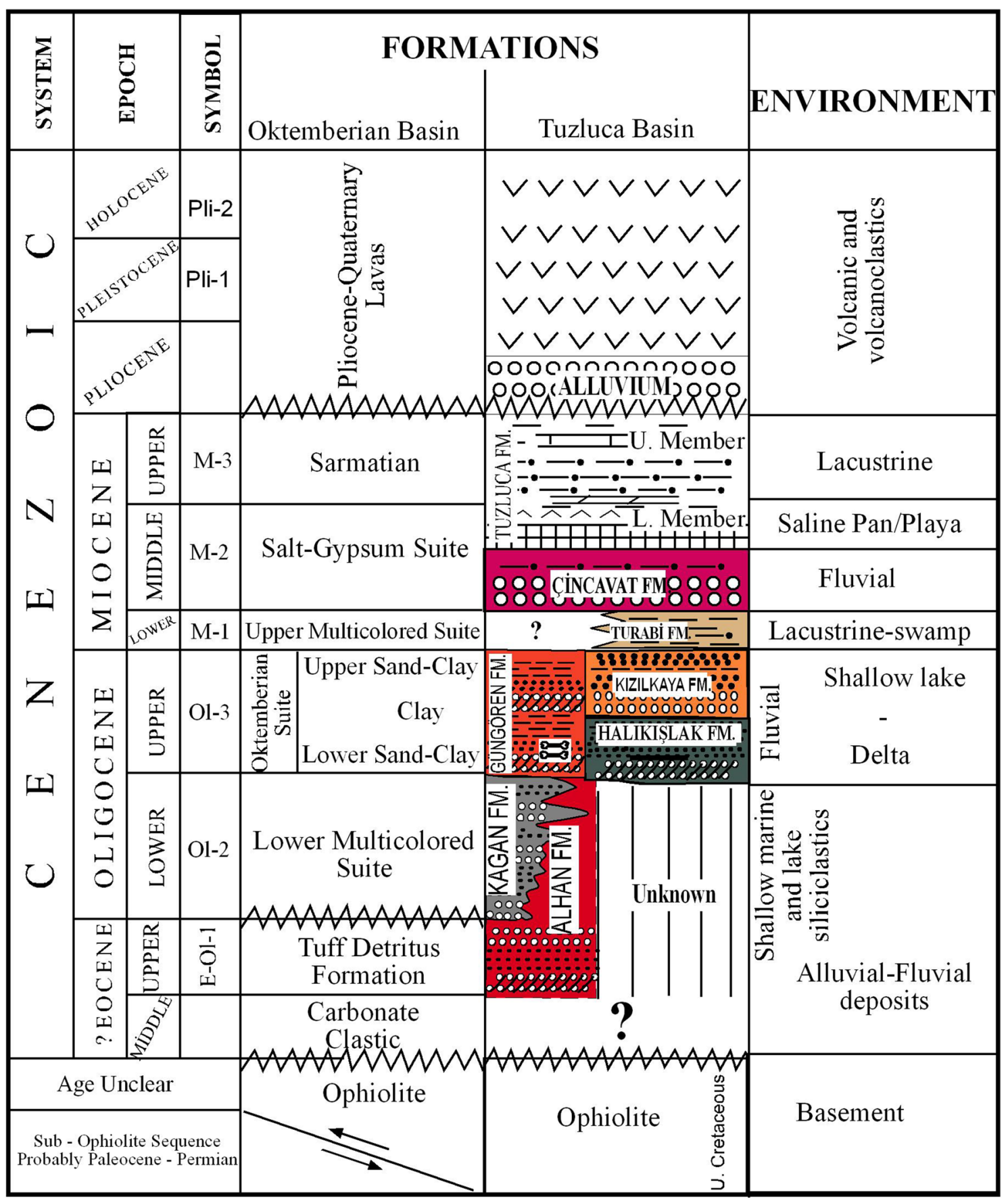

Fig. 3 Comparative stratigraphic columnar section of the studied area and Oktemberian basin (modified from Papworth and Aghabalyan 2002a; Varol et al. 2016)

\section{Sedimentary units}

Alhan Formation is the first stratigraphic unit over the basement, dominated by alluvial valley-fill deposits consisting of conglomerates, sandstones and mudstones with a thickness between 100 and $650 \mathrm{~m}$. There is no paleontological dating for this formation. It assigned a Late Eocene-Early Oligocene age, and it is a lateral equivalent unit of the Kağan
Formation with Early Eocene marine fossils, and conformably covering the Güngören Formation that includes Late Oligocene fossil mammal taxa (Şen et al. 2011; Métais et al. 2015; Varol et al. 2016). The Kağan Formation outcrops are observed in the SW of the basin (Hamurkesen, Güngören anticline), consisting of fluvial, coastal and alluvial deposits alternating with nummulite-bearing sandy limestones that resulted from an Early Oligocene transgression (Altınlı 
1966; Varol et al. 2011). The Güngören Formation conformably overlies the Alhan Formation (Figs. 2, 3) and is composed of lacustrine and meandering river channels and overbank deposits, evidenced by the Late Oligocene rhinoceros bones (Şen et al. 2011). In the northern part of the basin, this formation is replaced with Halıkışlak and Kızılkaya formations dominated by fluvial/ fluvial fan, and lacustrine delta deposits. Its age was determined as Late Oligocene based on the dating of pollen and spores (Sancay 2005; KayseriÖzer et al. 2017) and freshwater molluscs (Varol et al. 2011, 2016). The strata also are known as the Kömürlü Formation in the Kars and Ardahan area where its age ranges from Late Oligocene to Early-(Middle?) Miocene (Sungurlu 1971; Şahintürk and Kasar 1980). Swamp deposits within the deltaic sediments of the unit were sampled for organic content analysis (Figs. 3, 4, 5a). The Kizılkaya Formation consists of thick siliciclastic deposits ranging from red mudstones to coarse conglomerates with minor carbonates deposited in lacustrine and fluvial-lacustrine settings.
The Turabi Formation presents as basin-center setting and gradually overlies the Kizılkaya Formation (Figs. 2, $3,4)$. The Turabi Formation is composed generally of two main depositional packages: The first package starts with alternations of sandstone, and gravelly sandstone, followed by a cream-colored carbonaceous mudstone $(110 \mathrm{~m})$, indicating a fluvial-lacustrine transition zone (Varol et al. 2016). The second package is interbedded organic-rich mudstones, peat/lignite, with siliciclastic components that are up to $30 \%$ in some layers (Fig. 5 b, c). Single selenite gypsum crystals and minor framboidal pyrite $(5-10 \%)$ within the organic-rich mudstones probably formed diagenesis processes via bacterially-reduced sulphate (Garcia et al. 2001; Scheiber and Baird 2001). The Turabi Formation is overlain by 800 -m-thick red beds (Çincavat Formation), mainly composed of ephemeral stream, caliche and flood plain deposits (Fig. 4) with small mammalian fossils and terrestrial gastropods dated as Early Middle Miocene (Şen et al. 2011).

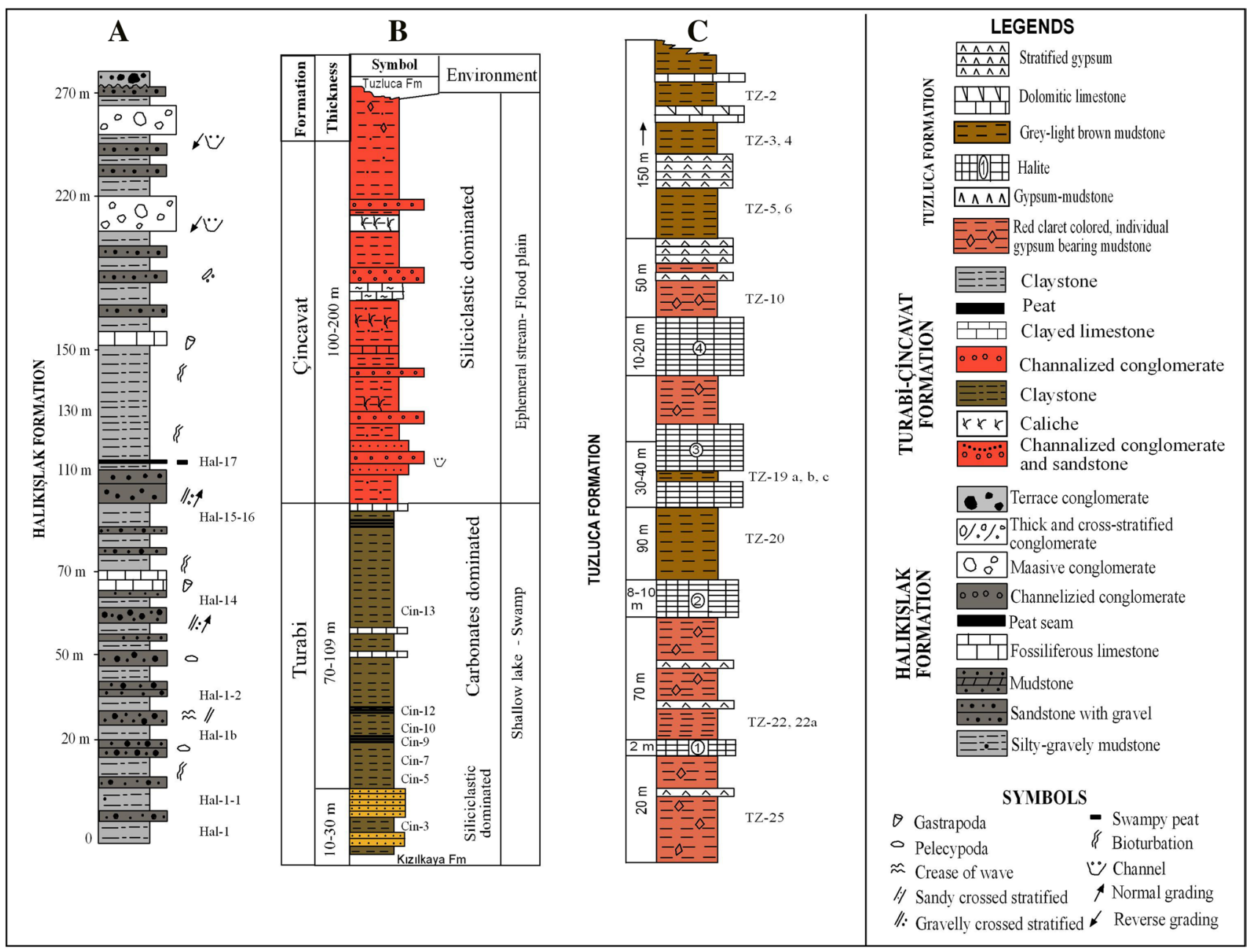

Fig. 4 Sedimentologic logs of the Tertiary units in the Kağızman-Tuzluca Basin 


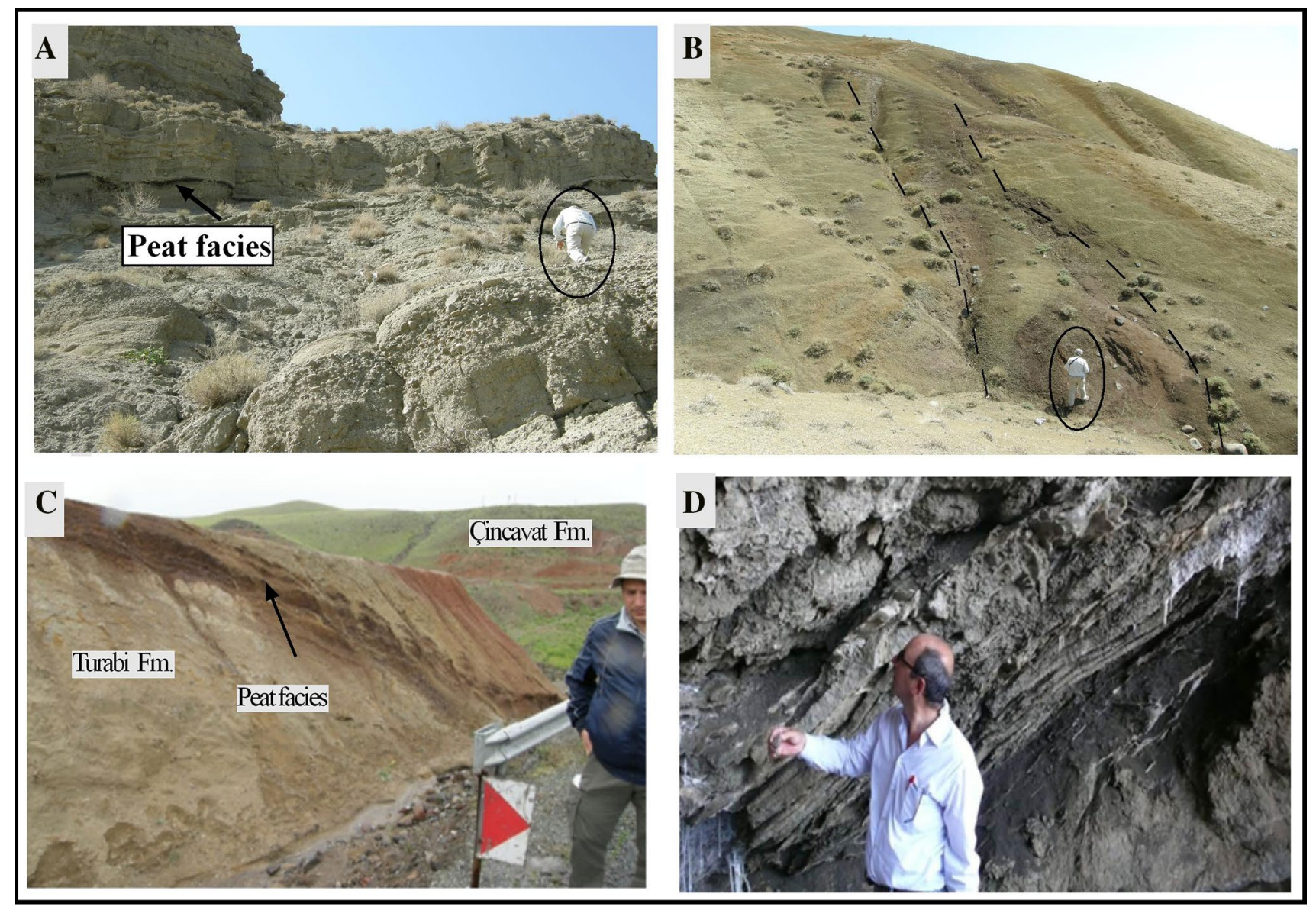

Fig. 5 a Small fan delta clastics bearing peat facies at the Halıkışlak section, $\mathbf{b}$ panoramic view of organic rich mudstone and thick peat facies within the Turabi Formation, $\mathbf{c}$ close view of peat and mud-

These units gradually turn into the evaporite-dominated Tuzluca Formation, deposited in shallow lake environment or saline pans and consisting of halite and dark-colored mudstones (Figs. 3, 4, 5d) overlain by gypsum and greyish-brown mudstones and dolomite. These units are interpreted as the Tuzluca Formation and an Undifferentiated Unit by Varol et al. (2016). In this study, we consider this unit as Tuzluca Formation, which is divided into Lower Member and Upper Member (Fig. 3). Its stratigraphic position and equivalence to the Salt-Gypsum Suite and Sarmatian in the Oktemberian Basin (Middle to Upper Miocene) suggests a Late Middle to Late Miocene age (Varol et al. 2011). Commercial salt deposits are present in the Tuzluca Formation and 11 salt mines are located to the east of Tuzluca. Cenozoic basins in Eastern Anatolia experienced intensive volcanism between the Middle/ Late Miocene and the Holocene (Fig. 3). Ağrı Mountain (known as Mount Ararat), located on the eastern margin of the KTB, is one of the main eruption centers (Ercan et al. 1987; Karakhanian et al. 2002). stone in the Turabi lacustrine facies (Tuzluca-Iğdır high way); d black mudstone alternation with halite layers in the Tuzluca Formation at the Tuzluca salt

\section{Materials and methods}

A total of 36 rock samples from three measured sections (Fig. 2) was obtained for organic geochemical analysis from the Kağizman-Tuzluca Basin. Eight samples were taken from the Halıkışlak Formation at the Halıkışlak Measured Section $\left(40^{\circ} 08^{\prime} 46.36^{\prime \prime} \mathrm{N} ; 43^{\circ} 38^{\prime} 44.60^{\prime \prime} \mathrm{E}\right.$; top at $\left.40^{\circ} 08^{\prime} 55.53^{\prime \prime} \mathrm{N} ; 43^{\circ} 38^{\prime} 25.26^{\prime \prime} \mathrm{E}\right)$ and consist of grey mudstones and silts; one sample was a peat-bearing mudstone facies. Thirteen samples were selected from the Turabi Formation at Köprübaşı (Çincavat) (N 40 $03^{\prime} 17.82^{\prime \prime}-\mathrm{E}$ $43^{\circ} 44^{\prime} 2.18^{\prime \prime}$; top at N 40 $\left.06^{\prime} 51.77^{\prime \prime}-\mathrm{E} 43^{\circ} 37^{\prime} 38.42^{\prime \prime}\right)$. Fifteen samples came from the Tuzluca Formation from extensive outcrops around the Tuzluca. The section was measured at $40^{\circ} 2^{\prime} 59.50^{\prime \prime} \mathrm{K}-43^{\circ} 39^{\prime} 59.21^{\prime \prime} \mathrm{E}$; top at: $40^{\circ} 2^{\prime} 57.14^{\prime \prime}$ $\mathrm{K}-43^{\circ} 40^{\prime} 9.43^{\prime \prime} \mathrm{E}$.

Bulk geochemical parameters were obtained by RockEval pyrolysis (Lafargue et al. 1998) at the Turkish Petroleum Corp., (TPAO) Research Center in Ankara using a Rock Eval-6 (RE-6) instrument with IFP 160,000 (Institut 


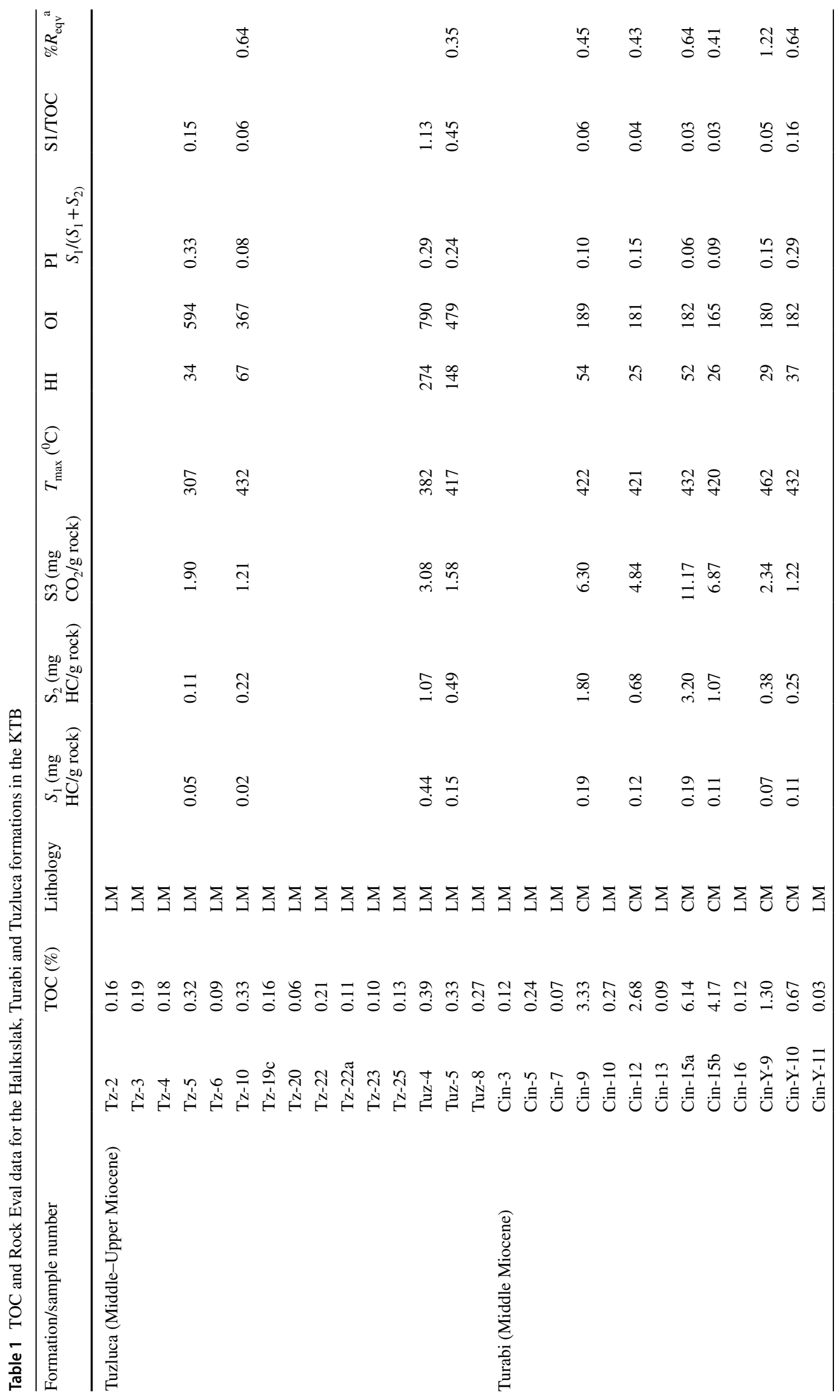




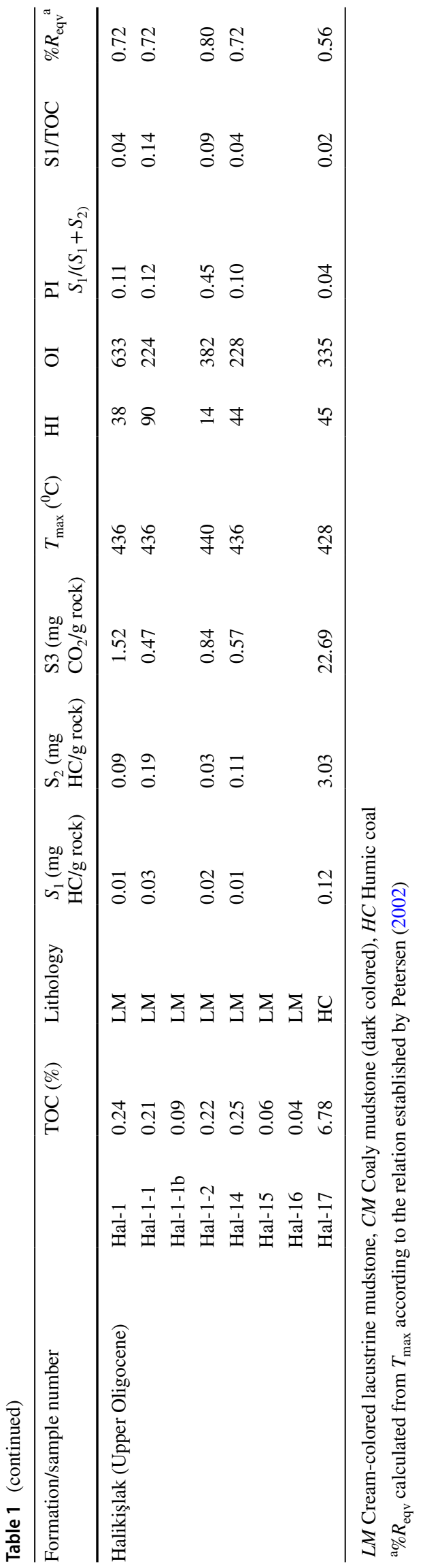

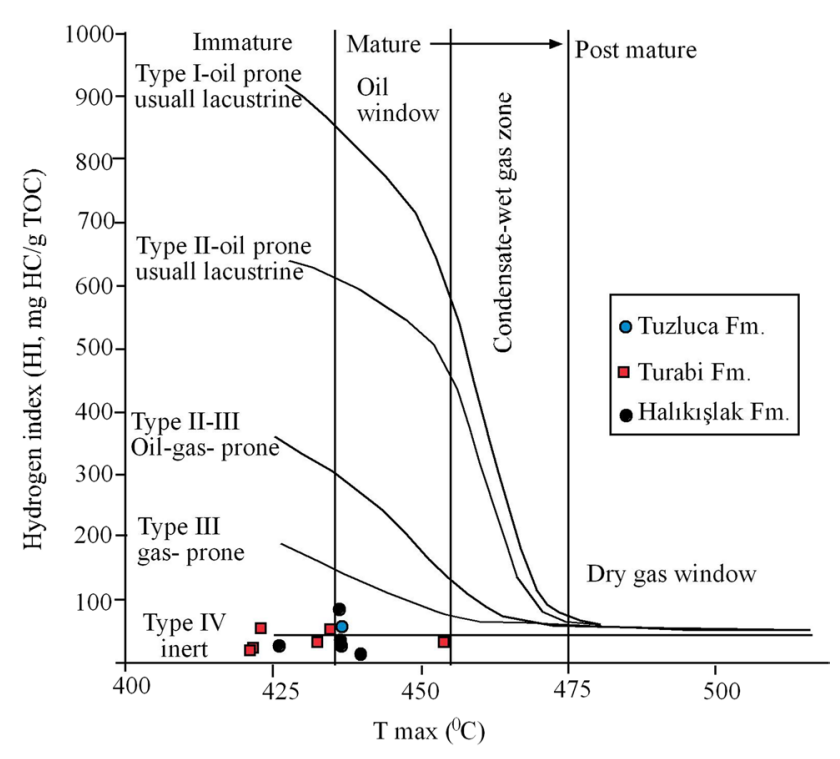

Fig. 6 Plot of hydrogen index (HI) versus pyrolysis $T_{\max }$ for the analyzed peat and shale sediments, showing kerogen quality and thermal maturity stages (modified after Mukhopadhyay et al. 1995)

Francais du Petrole) standards (Table 1). Additional parameters calculated from the pyrolysis data are the hydrogen index $\left(\mathrm{HI}=\mathrm{S}_{2} \times 100 / \mathrm{TOC}\right)$, oxygen index $\left(\mathrm{OI}=S_{3} \times 100 /\right.$ TOC), and production index $\left(\mathrm{PI}=S_{1} /\left(S_{1}+S_{2}\right)\right.$, normalized oil content $\left(S_{1} \times 100 / T O C\right)$. Equivalent reflectance values (\%Reqv) were derived from the measured $T_{\max }$ values from the correlation $T_{\max }=51.96 \% R+398.39$ (cf. Petersen 2002). Organic petrographic analyses were performed with a Leica DM 2500P model microscope at the TPAO Research Center, Ankara.

Extracts from two shale samples from the Halıkışlak (Hal17) and Turabi formations (Cin-15a) were analyzed by GC and GC-MS. GC analysis was conducted on an Agilent 6850 using a HP-1 SIMDIST column $(15 \mathrm{~m} \times 0.53 \mathrm{~mm} \times 0.15 \mu \mathrm{m})$ equipped with a FID. GC-MS analysis is performed by Agilent 7890A GC-5975C MS instrument with Agilent 7683B auto sampler. HP-1 MS capillary column $(60 \mathrm{~m} \times 0.25 \mathrm{~mm} \times 0.25 \mu \mathrm{m})$ is assigned. Helium is used as the carrier gas. Specify temperature program is used in the $\mathrm{GC}$ and GC-MS analyses.

\section{Geochemical results}

The TOC values of the Halıkışlak Formation (Table 1) varied between 0.04 and $0.25 \mathrm{wt} \%$ (average: $0.15 \mathrm{wt} \%$, except a single sample with $6.78 \mathrm{wt} \%$ ) indicating as poor source rock potential. Hydrogen Index (HI) values for the Halıkışlak Formation, including the high TOC-bearing sample, are $14-90 \mathrm{mg} \mathrm{HC} / \mathrm{g}$ TOC $(\times 100)$, and oxygen index values (OI) are 224-633 $\mathrm{mg} \mathrm{CO}_{2} / \mathrm{g}$ TOC $(\times 100)$, indicative of possibly 
oxidized organic matter. $T_{\max }$ values ranging from 428 to $440{ }^{\circ} \mathrm{C}$ and vitrinite reflectance $\left(\% R_{\text {eqv }}\right)$ values ranging from 0.56 to $0.80 \%$ (Table 1 ) are in the immature to mature source rocks. A plot of HI versus $T_{\max }$ (Fig. 6) shows that all the Halıkışlak Formation samples contain mainly kerogen Type III and IV. According to $S_{2}$ versus TOC wt $\%$ diagram, those samples are plotted in the poor source rock (Fig. 7).

The Turabi Formation possesses variable TOC values. Cream-colored mudstones samples of the lower part of Formation have relatively low TOC (ranging from 0.03 to $0.27 \mathrm{wt} \%$ ), and coaly mudstones (CM) intervals indicate higher TOC values (up to $6.14 \mathrm{wt} \%$ ). HI values of CM samples are between 29 and $54 \mathrm{mg} \mathrm{S}$ HC/ g TOC $(\times 100)$, and oxygen index values are $165-189 \mathrm{mg} \mathrm{CO} / \mathrm{g}$ TOC $(\times 100)$. The two organic matter rich mudstones were analyzed with organic petrographic method. Alginite organic matter is not found in sample CinY9, while it is present in minor proportions (\% 5) in sample Cin-15a. They contain mainly herbaceous and woody organic materials (Table 2). Minor framboidal pyrite was observed in sample Cin-15a which is a huminite minor coal with a reflectance of $0.46 \% R$ o. Rock-Eval $T_{\max }$ values, range between 420 and 432, and one sample is $462{ }^{\circ} \mathrm{C}$. About $90 \%$ of the samples have $T_{\max }$ $<435{ }^{\circ} \mathrm{C}$ (Peters 1986) indicating that they are mainly immature. In $S_{2}$ versus TOC wt\% diagram, those samples are plotted in the good to excellent source rock potential (Fig. 7). Based on the $S_{2}$ yield, only a single sample is of poor quantity. The TOC wt $\%$ and $S_{2}(0.11-1.07)$ values for the Tuzluca Formation are very low, indicating no source rock potential (Table 1; Fig. 7). This is confirmed by the
Fig. 7 The distribution of the Halıkışlak, Turabi and Tuzluca shale samples on S2 vs. TOC wt\% source rock classification diagram (after Dembicki 2009)

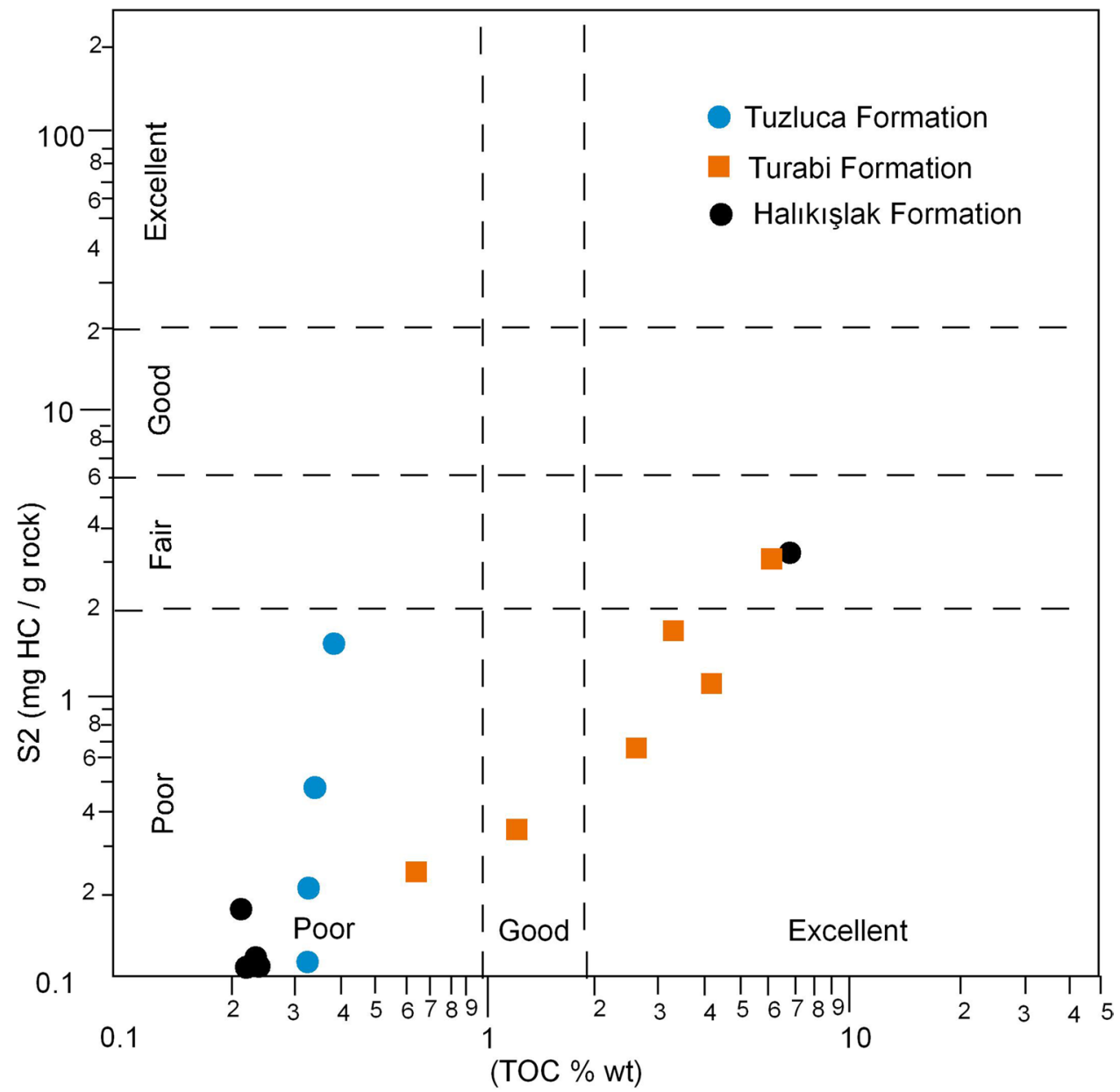

Table 2 Organic petrographic and kerogen-type compositions (vol\%) and mean vitrinite reflectance (random) values (nd not determined)

\begin{tabular}{llllllll}
\hline Formation & Sample number & Amorphous & Herbaceous & Woody & Coaly & SCI & $\%$ R \\
\hline Turabi & Cin-15a & 5 & 25 & 65 & 5 & nd & 0.46 \\
& Cin-Y9 & n.d & 80 & 20 & nd & nd & nd \\
\hline
\end{tabular}


$\mathrm{S}_{2}$ versus TOC wt $\%$ diagram. $T_{\max }$ values indicate the low thermal maturity $\left(307-432{ }^{\circ} \mathrm{C}\right)$.

$S_{1} /$ TOC values for the Halıkışlak, Turabi and Tuzluca formations range from 0.02 to $0.14,0.03$ to 0.16 and 0.06 to $1.13 \mathrm{mg} \mathrm{oil} / \mathrm{g}$ TOC, respectively, and the production index range from 0.04 to $0.45,0.06$ to 0.29 and 0.08 to 0.33 , respectively (Table 1). Though some samples belonging to the Turabi Formation are in the good area in Fig. 7, based on low $\mathrm{S}_{1} / \mathrm{TOC}$ and PI values are less than 0.2 except one sample (Peters 1986; Hunt 1996), it seems that HC generation has not occurred from the Turabi Formation.

\section{GC analysis}

Specific parameters were calculated from GC chromatograms of samples Cin-15a and Hal-17 (Fig. 8) and are presented in Table 3. $\mathrm{Pr} / \mathrm{Ph}$ ratios of samples are determined as 3.33 and 2.0, respectively (Table 3 ). Oil and condensates derived from organic matter rich in lakes, fluvial and deltaic sediments of $\mathrm{Pr} / \mathrm{Ph}$ ratio is greater than 3 (Connan and Cassou 1980). Evenick (2016) compared the XRD results with the $\mathrm{Pr} / \mathrm{Ph}$ ratios and suggest that $\mathrm{Pr} / \mathrm{Ph}$ ratio is greater than 2.5, indicating terrestrial organic facies. $\mathrm{Pr} / \mathrm{Ph}>1$ and high odd-even carbon dominance ratio (CPI $>1$ ) indicate terrestrial components (Peters et al. 2000). CPI is also used as the maturity parameter. For example, CPI $>5$ indicates immature resource rocks containing terrestrial high plants (Bray and Evans 1961). As a maturity parameter, it is about 1 for mature shale and petroleum, while it is high values (from 5 to 10) in immature sediments.

Isopronoid ratios $(\mathrm{Pr} / \mathrm{nC} 17-\mathrm{Ph} / \mathrm{n}-\mathrm{C} 18)$ are used to interpret the depositional conditions of the source rocks (Shanmugam 1985). On the $\mathrm{Pr} / \mathrm{nC} 17-\mathrm{Ph} / \mathrm{nC} 18$ graph, petroleum derived from terrestrial materials is represented by a pinkcolored area, a purple-colored area on a reduced marine
Table $3 \mathrm{Pr} / \mathrm{Ph}$ ratios and CPI values of the studied samples

\begin{tabular}{llllll}
\hline Sample number & Pr/Phy & Phy/Pr & Pr/n-C17 & Phy/n-C18 & CPI 16-32 \\
\hline Cin-15a & 3.33 & 0.30 & 0.37 & 0.25 & 2.35 \\
Hal-17 & 2.00 & 0.50 & 2.33 & 1.40 & 2.20 \\
\hline
\end{tabular}

environment, and a mixed organic matter yellow-colored area (Fig. 9). The high $\mathrm{Pr} / \mathrm{Ph}$ and CPI ratios in the samples indicate an immature terrestrial dominant-mixed organic matter.

\section{Biomarkers}

Ion chromatograms of the shally and coaly samples from the Turabi (Cin-15a) and Halıkışlak formations (Hal-17) and are presented in Fig. 10. Low tricyclic terpane concentration in both samples in $\mathrm{m} / \mathrm{z} 191$ chromatograms and dominant C29 $\alpha \alpha \alpha(20 \mathrm{R})$ in the $m / z, 217$ chromatograms indicate an immature source rock. The dominant 16R peak in the $m / z, 191$ chromatogram of Turabi samples indicate that the formation was deposited in a clastic-dominated environment. The same maturation and depositional environments are indicated by similar biomarker ratios: Tm/Ts $>1, \mathrm{C}_{29}$ Nor $/ \mathrm{C}_{30} \mathrm{Hop}<1$ ratios in the $m / z, 191$ chromatograms and also $\% \mathrm{C}_{29} \alpha \alpha \alpha$ (20R) peak are higher than $\% \mathrm{C}_{27} \alpha \alpha \alpha(20 \mathrm{R})$ and $\% \mathrm{C}_{28} \alpha \alpha \alpha$ (20R) in the $m / z 217$ chromatograms (Fig. 10; Tables 3, 4).

According to Mello et al. (1988), the Ts/Tm ratio is below 1.0 in lacustrine/saline, marine evaporitic or marine carbonates, while it is above 1 in lacustrine, freshwater or marine-deltaic environments. The lower of Ts/Tm ratio for Cin-15a number sample and not having Ts but the presence of gammacerene for the Hal-17 number sample showed that these samples may have precipitated in the lake/saline environment (Table 4). In
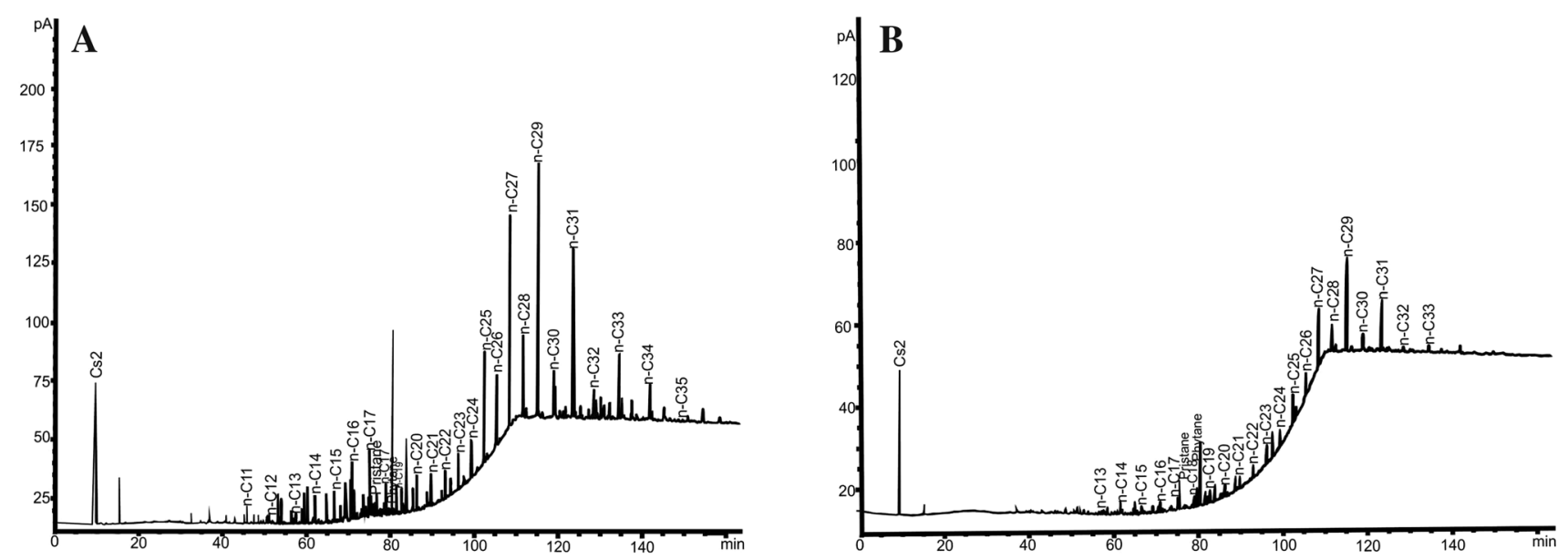

Fig. 8 Gas chromatograms for the whole extract from the shale samples and humic coal from Turabi and Halıkışlak formation, a Turabi and $\mathbf{b}$ Halıkışlak formation's samples 
Fig. 9 Pristane/nC17 versus Phytane/nC18 diagram. (4133 35: Turabi Fm., 4133 36: Halıkışlak Fm.)

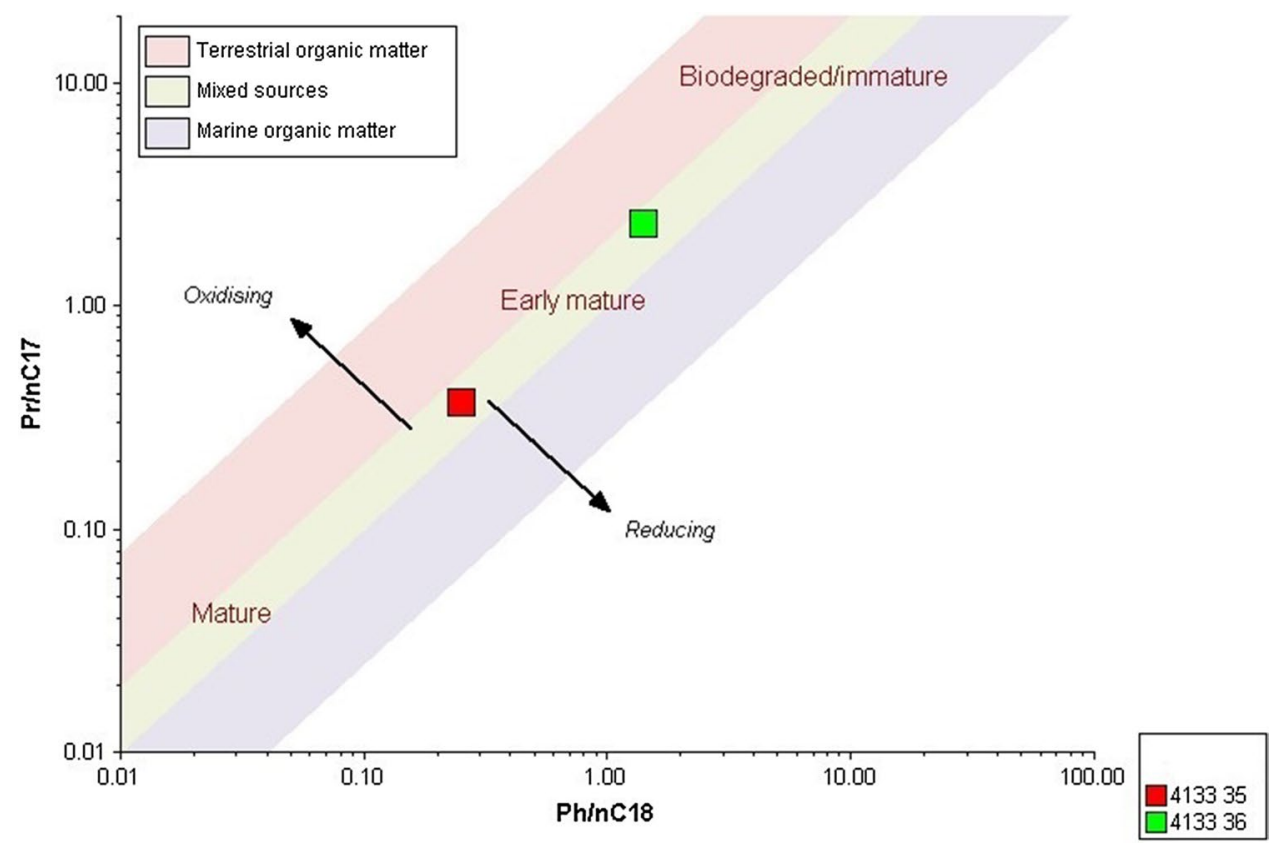

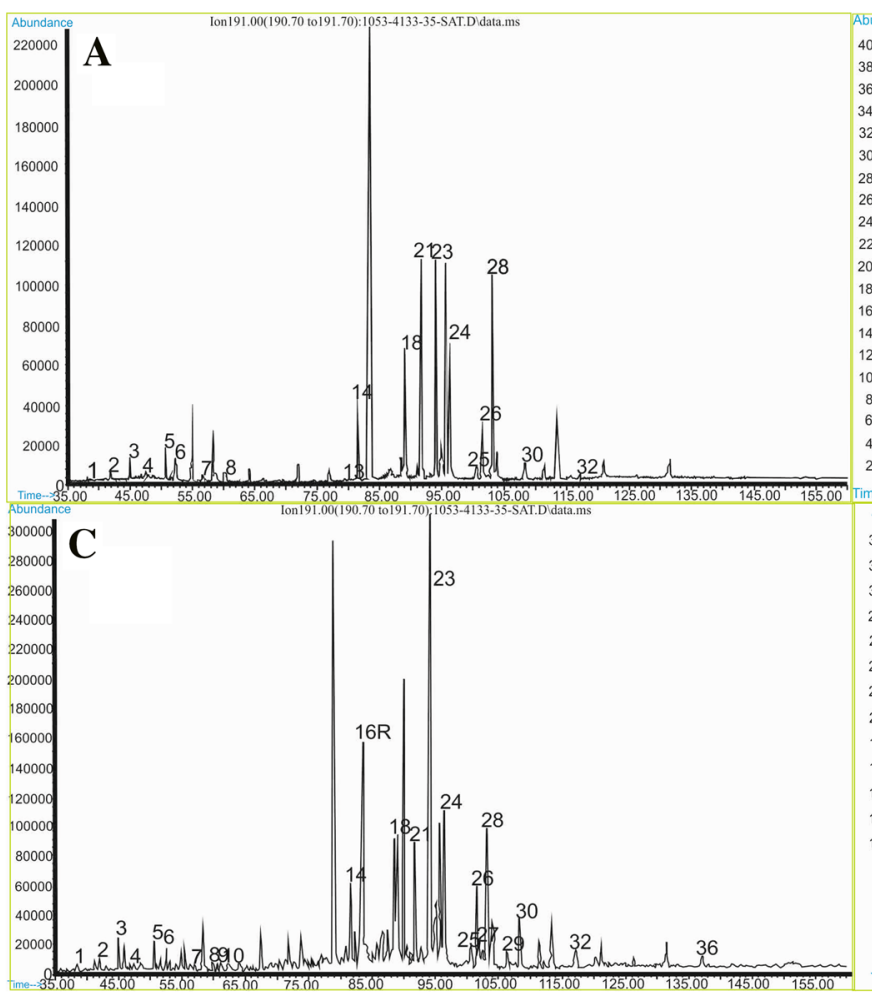

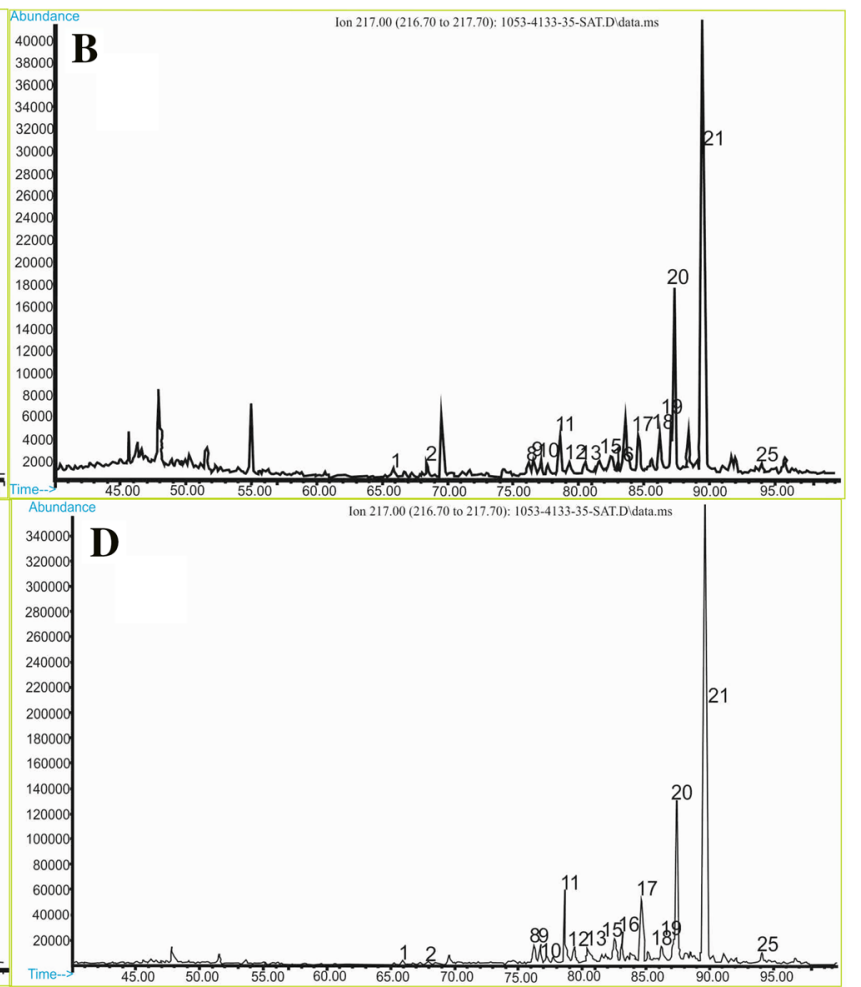

Fig. $10 \mathrm{~m} / \mathrm{z} 191$ and 217 mass chromatograms of Turabi shale sample (Cin-15a) (a, b), (c, d) m/z 191 and 217 mass chromatograms of Halıkışlak peat samples (a, b) (Hal-17)

addition, dominance of hopan to norhopan also pointed to terrestrial materials (Peters and Moldowan 1993). The low number of terpans in the distribution of terpenes is probably due to the very low maturation. The low rates of $C 29 \beta \beta / \alpha \alpha+\beta \beta(0.27-0.28)$ and diasteran values show immature source rock (Fig. 11). 
Table 4 GC-MS results of Halıkışlak and Turabi formations samples

\begin{tabular}{|c|c|c|c|}
\hline \multicolumn{2}{|l|}{ Terpan Parameters } & \multicolumn{2}{|l|}{ Steran Parameters } \\
\hline \multicolumn{4}{|c|}{ 1053-4133-35 (Turabi Fm.-Cin-15a) } \\
\hline $\mathrm{C}_{19}$ Tri/C $\mathrm{C}_{23}$ Tri & 0.10 & DiaStr $(\%)$ & - \\
\hline $\mathrm{C}_{23}$ Tri/ $\mathrm{C}_{24}$ Tet & 3.57 & NorStr $(\%)$ & - \\
\hline $\mathrm{C}_{23}$ Tri/ $\mathrm{C}_{30}$ Hop & 0.16 & IsoStr $(\%)$ & - \\
\hline $\mathrm{C}_{24}$ Tri/ $\mathrm{C}_{23}$ Tri & 0.61 & $\% \mathrm{C}_{27} \alpha \alpha \alpha(20 \mathrm{R})$ & 7.56 \\
\hline $\mathrm{C}_{24}$ Tet/ $\mathrm{C}_{23}$ Tri $+\mathrm{C}_{24}$ Tet & 0.22 & $\% \mathrm{C}_{28} \alpha \alpha \alpha(20 \mathrm{R})$ & 7.56 \\
\hline $\mathrm{C}_{24}$ Tet/ $\mathrm{C}_{26}$ & - & $\% \mathrm{C}_{29} \alpha \alpha \alpha(20 \mathrm{R})$ & 84.88 \\
\hline $\mathrm{C}_{24}$ Tet/ $\mathrm{C}_{30}$ Hop & 0.05 & $\mathrm{C}_{27} \alpha \alpha \alpha 20(\mathrm{~S} / \mathrm{R})$ & 0.24 \\
\hline $\mathrm{Tm} / \mathrm{Ts}$ & 24.00 & $\mathrm{C}_{28} \alpha \alpha \alpha 20(\mathrm{~S} / \mathrm{R})$ & 0.35 \\
\hline $\mathrm{Ts} / \mathrm{Tm}$ & 0.04 & $\mathrm{C}_{29} \alpha \alpha \alpha 20(\mathrm{~S} / \mathrm{R})$ & 0.09 \\
\hline $\mathrm{Ts}+\mathrm{Tm} / \mathrm{C}_{29}$ Nor & 0.34 & $\mathrm{C}_{27} \operatorname{RegStr}(\%)$ & - \\
\hline $\mathrm{Ts}+\mathrm{Tm} / \mathrm{C}_{28}-\mathrm{C}_{29}$ Tri & 0.68 & $\mathrm{C}_{28} \operatorname{RegStr}(\%)$ & - \\
\hline $\mathrm{C}_{28}-\mathrm{C}_{29}$ Tri/Tri + Hop & 0.00 & $\mathrm{C}_{29} \operatorname{RegStr}(\%)$ & - \\
\hline $\mathrm{C}_{29}$ Nor/C $\mathrm{C}_{30}$ Hop & 0.61 & $\mathrm{C}_{27} / \mathrm{C}_{29}$ & 0.09 \\
\hline Oleanene Index & 0.00 & $\mathrm{C}_{28} / \mathrm{C}_{29}$ & 0.09 \\
\hline Moretane Index & 0.38 & DiaStr/RegStr & 0.06 \\
\hline $\mathrm{C}_{30}$ Hop/C $\mathrm{C}_{31}$ Homohop & 2.90 & $\begin{array}{l}\mathrm{C}_{27} \beta \alpha \text { DiaStr/RegStr } \alpha \alpha \alpha \\
20 \mathrm{R}\end{array}$ & 0.05 \\
\hline Gammacerane Index & 0.00 & $\mathrm{C}_{27} \beta \beta / \alpha \alpha+\beta \beta$ & 0.39 \\
\hline $\mathrm{C}_{32} 22 \mathrm{~S} / \mathrm{C} 3222 \mathrm{~S}+22 \mathrm{R}$ & 0.00 & $\mathrm{C}_{28} \beta \beta / \alpha \alpha+\beta \beta$ & - \\
\hline $\mathrm{C}_{35} / \mathrm{C}_{34}$ & - & $\mathrm{C}_{29} \beta \beta / \alpha \alpha+\beta \beta$ & 0.32 \\
\hline $\mathrm{C}_{27}$ DiaStr $(\%)$ & & & 55.56 \\
\hline $\mathrm{C}_{28}$ DiaStr (\%) & & & 0.00 \\
\hline $\mathrm{C}_{29} \operatorname{DiaStr}(\%)$ & & & 44.44 \\
\hline \multicolumn{4}{|c|}{ 1053-4133-36-(Halıkışlak Fm. Hal-17) } \\
\hline $\mathrm{C}_{19}$ Tri/C $\mathrm{C}_{23}$ Tri & 0.15 & DiaStr $(\%)$ & 3.63 \\
\hline $\mathrm{C}_{23}$ Tri/ $\mathrm{C}_{24}$ Tet & 2.67 & NorStr $(\%)$ & 68.72 \\
\hline $\mathrm{C}_{23}$ Tri/ $\mathrm{C}_{30}$ Hop & 0.06 & IsoStr $(\%)$ & 27.65 \\
\hline $\mathrm{C}_{24}$ Tri/C $\mathrm{C}_{23}$ Tri & 0.63 & $\% \mathrm{C}_{27} \alpha \alpha \alpha(20 \mathrm{R})$ & 12.20 \\
\hline $\mathrm{C}_{24}$ Tet/ $\mathrm{C}_{23}$ Tri $+\mathrm{C}_{24}$ Tet & 0.27 & $\% \mathrm{C}_{28} \alpha \alpha \alpha(20 \mathrm{R})$ & 11.59 \\
\hline $\mathrm{C}_{24}$ Tet/ $\mathrm{C}_{26}$ & 0.50 & $\% \mathrm{C}_{29} \alpha \alpha \alpha(20 \mathrm{R})$ & 76.22 \\
\hline $\mathrm{C}_{24}$ Tet/C ${ }_{30}$ Hop & 0.02 & $\mathrm{C}_{27} \alpha \alpha \alpha 20(\mathrm{~S} / \mathrm{R})$ & 0.20 \\
\hline $\mathrm{Tm} / \mathrm{Ts}$ & 0.43 & $\mathrm{C}_{28} \alpha \alpha \alpha 20(\mathrm{~S} / \mathrm{R})$ & 0.00 \\
\hline $\mathrm{Ts} / \mathrm{Tm}$ & 2.33 & $\mathrm{C}_{29} \alpha \alpha \alpha 20(\mathrm{~S} / \mathrm{R})$ & 0.04 \\
\hline $\mathrm{Ts}+\mathrm{Tm} / \mathrm{C}_{29}$ Nor & 2.16 & $\mathrm{C}_{27} \operatorname{RegStr}(\%)$ & 13.11 \\
\hline $\mathrm{Ts}+\mathrm{Tm} / \mathrm{C}_{28}-\mathrm{C}_{29}$ Tri & 0.70 & $\mathrm{C}_{28} \operatorname{RegStr}(\%)$ & 13.11 \\
\hline $\mathrm{C}_{28}-\mathrm{C}_{29}$ Tri/Tri + Hop & 0.00 & $\mathrm{C}_{29} \operatorname{RegStr}(\%)$ & 73.77 \\
\hline $\mathrm{C}_{29}$ Nor/C $\mathrm{C}_{30}$ Hop & 0.30 & $\mathrm{C}_{27} / \mathrm{C}_{29}$ & 0.16 \\
\hline Oleanene Index & 0.00 & $\mathrm{C}_{28} / \mathrm{C}_{29}$ & 0.15 \\
\hline Moretane Index & 0.26 & DiaStr/RegStr & 0.04 \\
\hline $\mathrm{C}_{30}$ Hop/C $\mathrm{C}_{31}$ Homohop & 4.35 & $\begin{array}{l}\mathrm{C}_{27} \beta \alpha \text { DiaStr/RegStr } \alpha \alpha \alpha \\
20 \mathrm{R}\end{array}$ & 0.01 \\
\hline Gammacerane Index & 0.05 & $\mathrm{C}_{27} \beta \beta / \alpha \alpha+\beta \beta$ & 0.22 \\
\hline $\mathrm{C}_{32} 22 \mathrm{~S} / \mathrm{C} 3222 \mathrm{~S}+22 \mathrm{R}$ & 0.24 & $\mathrm{C}_{28} \beta \beta / \alpha \alpha+\beta \beta$ & 0.41 \\
\hline $\mathrm{C}_{35} / \mathrm{C}_{34}$ & 1.50 & $\mathrm{C}_{29} \beta \beta / \alpha \alpha+\beta \beta$ & 0.28 \\
\hline $\mathrm{C}_{27}$ DiaStr (\%) & & & 16.67 \\
\hline $\mathrm{C}_{28} \operatorname{DiaStr}(\%)$ & & & 0.00 \\
\hline $\mathrm{C}_{29}$ DiaStr $(\%)$ & & & 83.33 \\
\hline
\end{tabular}

C27 sterane dominance refers to marine phytoplankton, while C29 sterane dominance indicates strong terrestrial origin. The relative presence of at least C28 sterane in these three sterols indicates the contribution of lacustrine algae. According to Volkman (2003), C27 sterans predominantly dominate marine plankton, while $\mathrm{C} 28$ sterans are yeast, fungus, plankton and algae. In addition, C29 sterans may originate from higher plants (Volkman 1986) and brown-green algae (Volkman 2003).

In the samples, high \% C29 $\alpha \alpha \alpha$ (20R) indicates terrestrial organic matter contribution (Table 4). In addition, 20R and 20S epimeric forms $20 \mathrm{~S} /(20 \mathrm{~S}+20 \mathrm{R})$ ratio of $\alpha \alpha$ sterans are the most important parameters used for maturity measurement. In the biological configuration, while the $\alpha \alpha \alpha$ forms are $20 \mathrm{R}$, the maturity increases with the change in the configuration of the $20 \mathrm{~S}-20 \mathrm{R}$ residues. The maturity ratio of $\mathrm{C} 29 \alpha \alpha(\mathrm{S} /(\mathrm{S}+\mathrm{R}))$ reaches the equilibrium value in the oil generation window at $\sim 0.52$. However, this value and little above this value can cause misunderstanding and misinterpretation (Petersen et al. 2005).

\section{Discussion}

Lacustrine petroleum source rocks are important for the production of large volume of hydrocarbons in many basins (e.g., Carroll and Bohacs 2001; Obaje et al. 2004; Petersen et al. 2005; Tian et al. 2014). While neighboring Oktemberian and Lesser Caucasus basins that consist of time-equivalent successions, are being explored, the Kağizman-Tuzluca basin has not attracted attention. Varol et al. (2016) suggest that this basin was filled by overfilled and underfilled lake units alternating with fluvial deposits which is similar depositional properties to Oktemberian basin. These are the fluvial-lacustrine (Halıkışlak Formation), fluctuating profundal lake (Turabi Formation) and evaporates (Tuzluca Formation).

The Halıkışlak Formation was deposited in a wide range of environments from fluvial/alluvial to deep and shallow lakes with local swamps. TOC wt $\%$ of analyzed samples indicates no source rock potential according to the classification of Peters (1986). A peat-bearing mudstone-deposited local swamps have high TOCs; but HI and $T_{\max }$ values are quite low. The high $\mathrm{Pr} / \mathrm{Ph}$ and $\mathrm{CPI}$ ratios of the samples indicate an immature terrestrial dominant-mixed organic matter. However, $T_{\max }$ values for the other samples are between 436 and $440{ }^{\circ} \mathrm{C}\left(\% R_{\text {eqv }}\right.$ : ranging from 0.72 to 0.8$)$ indicating slightly mature characteristics. The samples were generally collected around the margin of the lacustrine basin, and north of the Halıkışlak is mostly covered by volcanics. Ercan et al. (1987) identified electrically conductive layers beneath the volcanic plateau with a thickness of about $1.5-2 \mathrm{~km}$ that overlies basement, which is gradually shallower from North

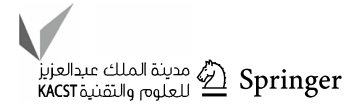


Fig. 11 C29 sterane isomerisation: S/R versus I/R diagram. (4133 35: Turabi Fm., 4133 36: Halıkışlak Fm.)

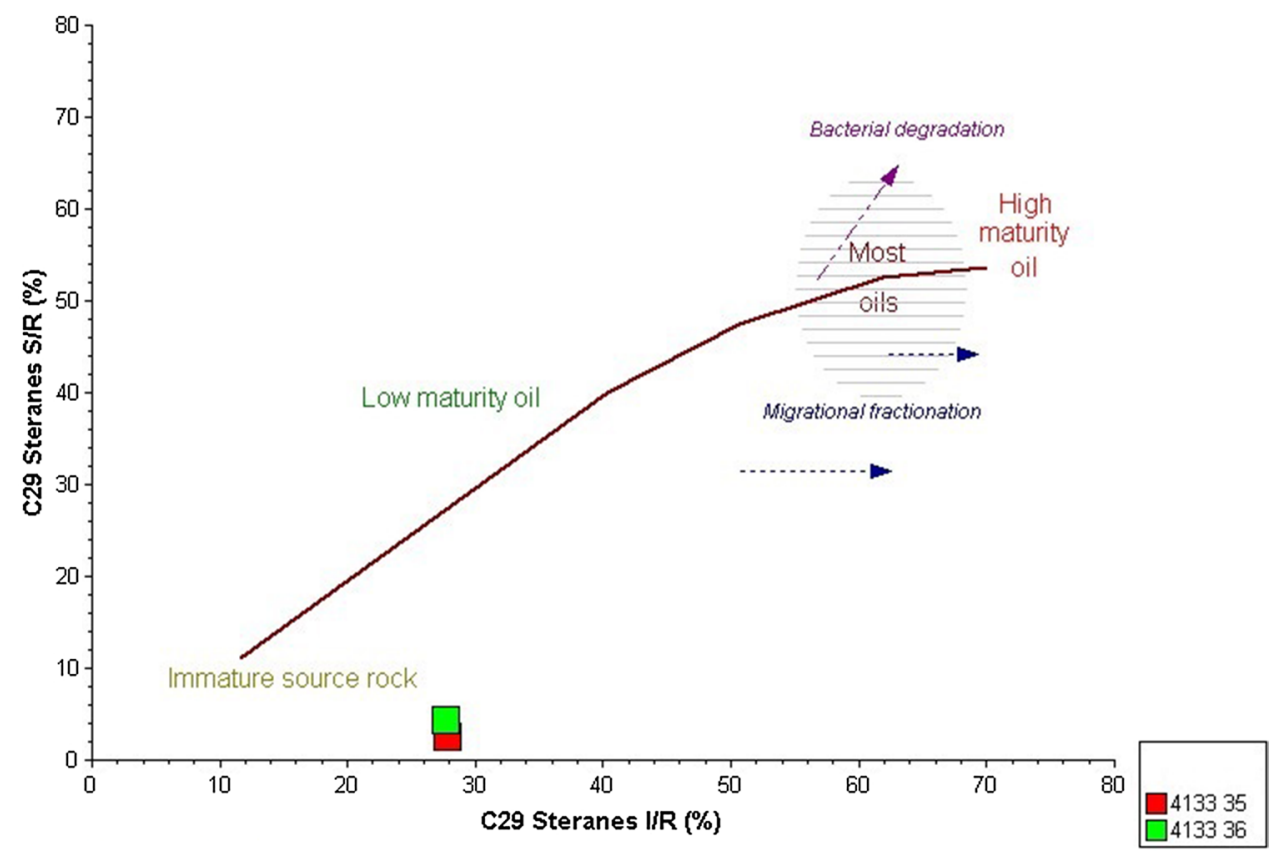

to South. In addition to this, Kömürlü Formation, which is contemporary to the Halıkışlak Formation in the northern part (Ardahan Basin and Kars Plateau), has different lithology and organic geochemical properties. It is composed of conglomerates, sandstones, and shale intercalations in the lower part, grading into laminated shales, marls, and coal layers with thin gypsum layers at the top of sequence (Şahintürk and Kasar 1979; Uğur 2000). TOC (\%) values of the Formation are very high (1.10-28.95 wt $\%), T_{\max }$ values vary between 436 and $442{ }^{\circ} \mathrm{C}$ and $\mathrm{HI}$ values are up to 827 mg HC/gTOC (Aydemir 2010, 2013). Aydemir (2010) also suggest that the Kömürlü Formation has great unconventional resources potential. Therefore, we suggest that the Halıkışlak Formation might be predicted as richer in organic matter under the volcanic area. However, an additional study clearly is needed to support this conclusion.

The Turabi Formation represents fresh water and alkaline lake units and it is divided into two sections: sandstone, coarse-grained sandstones and mudstone alternation, and a thick cream-colored mudstones facies composed of siltstone interbeds and organic matter-rich laminated mudstones (Varol et al. 2016). The formation is characteristic of the "fluvial-lacustrine facies association and algal organic facies" at lower and upper parts, respectively (Carroll and Bohacs 2001). The lower of Ts/Tm ratio and not having Ts value for Cin-15a number sample showed that the units may have deposited in the lake/saline environment. Organic petrographic results and $T_{\max }$ versus HI diagram show that kerogen types are III and II origin. Upper part of the Turabi Formation has mainly terrestrial organic matter. Organic petrography of two samples (Cin-9 and Cin-15a) indicates that they are rich in herbaceous and woody material, and less coaly with pyrite, and support "algal-terrestrial organic facies". Carroll and Bohacs (2001) suggest that this type's lacustrine facies includes some of the world's richest source rocks. Organic-rich mudstones facies represents potentially could be good source rock with the TOC values. Reported Rock-Eval $T_{\max }$ values for the Turabi samples vary greatly and are unreliable for samples with low $\mathrm{S}_{2}$ yields. High $T_{\max }$ values also can be the result of high oxidation. Considering only the $T_{\max }$ of higher TOC samples, the organic petrography and the biomarker analysis, the studied Turabi Formation samples are mainly immature to marginally mature source rock potential.

Gas shows from the two wells (during 6 months) may support that petroleum system exists in the basin in the Oktemberian Basin next to KTB. However, maturation of the organic rich clay was determined as immature (Papworth and Aghabalyan 2002b). They concluded that it is likely that much of the observed gas was originated at depth from more mature sediments from beneath the ophiolite, which forms a floor to the tertiary sediments in the basin (Papworth and Aghabalyan 2002b). In addition, non- economic gas was detected from two wells in the KTB (Şenalp 1969b). However, there has not been any published study about gas origin in both basins.

The Halıkışlak and Turabi formations could be equivalent to Maikop Formation that is exposed in the Shmekha-Gobustan area in Azerbaijan (Guliyev at al. 2000; Feyzullayev et al. 2001). Bechtel et al. (2013) concluded that these Oligocene sediments have Type II (marine/brackish) organic matter with low to moderate Type III kerogen inputs, indicating different depositional properties from the KTB. Therefore, we 
could say that the lithostratigraphic units of the studied units are not equivalent to the Maikop and are not rich in TOC wt\%.

The Tuzluca Formation is mainly composed of evaporites (halite, gypsum) with thin dark-colored mudstones in the lower part, and mainly green-colored claystone and dolomite alternation facies in the upper part. It is characterized by saline pan, sulphate lake and perennial lake units (Varol et al. 2016) and good seal rock properties in the basin. While TOC values are between 0.27 and $0.39 \mathrm{wt} \%$ for saline pan facies samples (Figs. 4c, 5d), that values are ranging from 0.06 to $0.33 \mathrm{wt} \%$ for the sulfate and perennial lake facies. Low $\mathrm{HI}$ and $T_{\max }$ values indicate that the evaporate-bearing facies have poor petroleum potential. However, there are limited outcrops around Tuzluca, covered by recent alluvial conglomerate, extending to Armenian border. Therefore, deep evaporitic lacustrine units were not sampled and analyzed in this study. In addition, $\mathrm{Br}$ content of salt samples show saline pan environment in the Tuzluca, though salt samples belonging to Nakhichevan area have marine signature values. The data suggest that the Tuzluca Formation and its equivalent to the eastern part have marine source rocks. The authors suggest that evaporite units should be studied more detailed in the eastern areas.

\section{Conclusions}

The Oligo-Miocene units in the KTB were deposited under different conditions from time equivalent to the Maikop Series. The studied basin has three types of lacustrine deposits. The Halıkışlak and Turabi formations have fluvial lacustrine facies and fluctuating profundal facies associations that could provide source rock beneath the volcanic cover at northern part of the study area. According to organic geochemical and sedimentological studies, non-economic gas shows in the Oligo-Miocene units in the studied basin might indicate that tertiary petroleum system exists for conventional resources. The Turabi and secondarily to the Halıkışlak formations should be tested in the future investigations when deeper boreholes become available from the proposed drilling program of the oil and gas exploration companies in KTB and beneath the Kars volcanic plateau.

\begin{abstract}
Acknowledgements The study in the Kağızman-Tuzluca Basin was granted by Turkish Council for Scientific and Technical Research (TUBITAK) under the Project number 108Y026. We are grateful to Ş. Şen, the DARIUS Research Program (France) (CNRS) for determination mammalian fossil in the terrestrial unit. Z. Dinçer Kırman (TPAO) for analyzing GC, GC-MS.
\end{abstract}

Open Access This article is distributed under the terms of the Creative Commons Attribution 4.0 International License (http://creativeco mmons.org/licenses/by/4.0/), which permits unrestricted use, distribution, and reproduction in any medium, provided you give appropriate credit to the original author(s) and the source, provide a link to the Creative Commons license, and indicate if changes were made.

\section{References}

Adamia S, Zakariadze G, Chkhotua T, Sadradze N, Tsereteli N, Chabukiani A, Gventsadze A (2011) Geology of the Caucasus: a review. Turk J Earth Sci 20:489-544

Altınlı IE (1966) Geology of eastern and Southeastern Anatolia. Bull Min Res Explor Inst Turkey 66:35-76

Aydemir A (2010) Potential Shale Gas resources in Turkey: Evaluating geological prospects, geochemical properties, surface access and infrastructure. Global Shale Gas Summit-2010, July 19-20, Warsaw, Poland

Aydemir A (2013) Potential unconventional formations in different basins of Turkey. International Shale Gas and Oil Conference of Turkey (ISGC-2013). February, 20-21, 2013, Ankara, Turkey

Ayyıldız T, Varol B, Karakaş Z, Sözeri K (2011) Organic geochemical evaluation of the Late Oligocene to Miocene aged units around Tuzluca (Iğdır), NE Turkey. 18th International Petroleum and Natural Gas Congress and Exhibition of Turkey, May $11^{\text {th }}-13$ th, $p 177$

Ayyıldız T, Varol B, Karakaş Z, Sözeri K (2012) Miocene Evaporites in the Intermountain Tuzluca -Iğdır Neogene Basin, Eastern Turkey. Vol. 14, EGU2012-8049, EGU General Assembly, Vienna, Austria

Balian SP (1969) Strukturnaia Geomorfologia Armianskogo Nagoriya i Okaimlyushikh Oblastei. Erevanskii Gosudarst Univ, Izdatels Erevansk Univ Erevan. p 390 (in Russian)

Bechtel A, Movsumova U, Strobl SAI, Sachsenhofer RF, Soliman A, Gratzer R, Puttmann W (2013) Organofacies and paleoenvironment of the Oligocene Maikop series of Angeharan (eastern Azerbaijan). Org Geochem 56:51-67

Bozkurt E (2001) Neotectonics of Turkey-a synthesis. Geodin Acta 14(1-3):3-30

Bray EE, Evans ED (1961) Distribution of $n$-paraffins as a clue to recognition of source beds. Geochim Cosmochim Acta 22(1):2-15

Carroll AR, Bohacs KM (2001) Lake-type controls on petroleum source rock potential in nonmarine basins. AAPG Bull 85:1033-1053

Çiftçi NB, Bozkurt E (2010) Structural evolution of the Gediz Graben, SW Turkey: temporal and spatial variation of the graben basin. Basin Res 22(6):846-873

Connan J, Cassou AM (1980) Properties of gases and petroleum liquids derived from Terrestrial kerogen at various maturation levels. Geochim Cosmochim Acta 44:1-23

Dembicki H Jr (2009) Three common source rock evaluation errors made by geologists during prospect or play appraisals. AAPG Bull 93(3):341-356

Dhont D, Chorowicz J (2006) Review of the neotectonics of the Eastern Turkish-Armenian Plateau by geomorphic analysis of digital elevation model imagery. Int J Earth Sci 95(1):34-49

Dhont D, Chorowicz J, Luxey P (2006) Anatolian escape tectonics driven by Eocene crustal thickening and Neogene-Quaternary extensional collapse in the eastern Mediterranean region. In: Dilek Y, Pavlides S (eds) Postcollisional tectonics and magmatism in the Mediterranean Region and Asia. Geological Society of America Special Paper, 409

Ediger V, Batı Z, Yazman M (1996) Palynology of possible hydrocarbon source rocks of the Alaşehir-Turgutlu area in the Gediz graben (western Anatolia): Turkish Association of. Pet Geol Bull 8:94-112

Ercan A, Genç T, Duygu MA (1987) Kalın bazalt örtüsü altının yerelektrik yöntemle çalışılması: Batı Kafkasya [Resistivity studies over the thick basalt cover, the western Caucasia]. Jeofizik 1:45-75

Eşder T (1967) Orta Aras Depresyon Bölgesinin 1/25000 Ölçekli Etüd Raporu. [1/25000 scaled survey report of the central Aras depression region] MTA Report No: 4243, p 105, Ankara

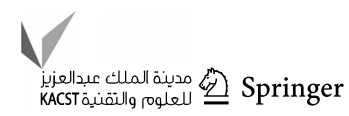


Eşder T (1968a) Orta Aras Depresyonu Bölgesinin 1/25 000 Ölçekli Detay Petrol Etüdü Raporu, Tuzluca-Iğdır. [1/25 000 scaled detailed petroleum survey report of the central Aras depression province, Tuzluca-Iğdır]. MTA Report no: 4243 (unpublished)

Eşder T (1968b) Tuzluca-1 kuyu bitirme raporu [Tuzluca-1 well final report]. MTA Report no: 4456 (unpublished)

Eşder T (1968c) Tuzluca-2 kuyu bitirme raporu [Tuzluca-2 well final report]. MTA Report no: 4457 (unpublished)

Evenick CJ (2016) Evaluating source rock organofacies and paleodepositional environments using bulk rock compositional data and pristine/phytane rations. Mar Pet Geol 78:507-515

Feyzullayev AA, Guliyev IS, Tagiyev MF (2001) Source potential of the Mesozoic-Cenozoic rocks in the South Caspian Basin and their role in forming the oil accumulations in the Lower Pliocene reservoirs. Pet Geosci 7:409-417

Gao G, Zhang W, Xiang B, Liu G, Ren J (2016) Geochemistry characteristics and hydrocarbon-generating potential of lacustrine source rock in Lucaogou Formation of the Jimusaer Sag, Junggar Basin. J Petrol Sci Eng 145:168-182

Garcia C, Moreno DA, Ballester A, Blazquez ML, Gonzalez F (2001) Bioremediation of an industrial acid mine water by metal-tolerant sulphate-reducing bacteria. Miner Eng 14(9):997-1008

García-Veigas J, Helvac1 C (2013) Mineralogy and sedimentology of the Miocene Göcenoluk borate deposit, Kırka district, western Anatolia, Turkey. Sed Geol 290:85-96

Göğüş OH, Pysklywec RN (2008) Mantle lithosphere driving plateau uplift and synconvergent extension in eastern Anatolia. Geology 36(9):723-726

Golonka J (2007) Geodynamic evolution of the South Caspian Basin. In: Yilmaz PO, Isaksen GH (eds) Oil and gas of the Greater Caspian area: AAPG Studies in Geology, vol 55, pp 17-41

Guliyev IS, Tagiyev MF, Feyzullayev AA (2001) Geochemical characteristics of organic matter from Maikop rocks of eastern Azerbaijan. Lithol Min Resour 36:280-285

Hässig M, Rolland Y, Sosson M, Galoyan G, Müller C, Avagyan A, Sahakyan L (2013) New structural and petrological data on the Amasia ophiolites (NW Sevan-Akera suture zone, Lesser Caucasus): Insights for a large scale obduction in Armenia and NE Turkey. Tectonophysics 588:135-153

Helvacı C, Orti F (1998) Sedimentology and diagenesis of Miocene colemanite-ulexite deposits (western Anatolia, Turkey). J Sediment Res 68(5):1021-1033

Hunt JM (1996) Petroleum geochemistry and geology, vol 2. WH Freeman, New York, pp 1-743

İnan S, Yalçın MN, Guliev IS, Kuliev K, Feyzullayev AA (1998) Deep petroleum occurrences in the Lower Kura Depression, South Caspian Basin, Azerbaijan: an organic geochemical and basin modelling study. Mar Pet Geol 14:731-762

İnci U (1991) Miocene alluvial fan-alkaline playa lignite-trona bearing deposits from an inverted basin in Anatolia: sedimentology and tectonic controls on deposition. Sediment Geol 71:73-97 (Amsterdam)

Karakhanian A, Djrbashian R, Trifonov V, Philip H, Arakelian S, Avagian A (2002) Holocene-historical volcanism and active faults as natural risk factors for Armenia and adjacent countries. J Volcanol Geoth Res 113:419-438

Kayseri-Özer MS, Sancay RH, Şen Ş, Sözeri K, Métais G, Ayyıldız T, Varol B (2017) Paleoenvironment of the Late Oligocene from the Kağizman-Tuzluca Basin (northeastern Anatolia) based on the micro-and macrofloras. Turkish J Earth Sci 26(3):227-248

Klett TR (2016) Geology and assessment of the undiscovered, technically recoverable petroleum resources of Armenia, 2013 (No. 69-PP). US Geological Survey

Koçyiğit A, Yılmaz A, Adamia S, Kuloshvili S (2001) Neotectonics of East Anatolian Plateau (Turkey) and Lesser Caucasus: implication for transition from thrusting to strike-slip faulting. Geodin Acta 14(1-3):177-195

Lafargue E, Marquis F, Pillot D (1998) Rock-Eval 6 applications in hydrocarbon exploration, production, and soil contamination studies. Rev Inst Fr Pet 53(4):421-437

Lerche I, Ali-Zadeh A, Guliyev I, Bagirov E, Nadirov R, Tagiyev MF, Feizullayev A (eds) (1997) South Caspian Basin: Stratigraphy, Geochemistry and Risk Analysis. Azerbaijan Academy of Sciences, Nafta Press, Baku

Mello MR, Gaglianone PC, Brassell SC, Maxwell JR (1988) Geochemical and biological marker assessment of depositional environments using Brazilian offshore oils. Mar Pet Geol 5:205-223

Métais G, Şen S, Sözeri K, Peigné S, Varol B (2015) Late Paleogene terrestrial fauna and paleoenvironments in Eastern Anatolia: new insights from the Kağizman-Tuzluca Basin. J Asian Earth Sci 107:96-109

Mukhopadhyay PK, Wade JA, Kruge MA (1995) Organic facies and maturation of Cretaceous/Jurassic rocks and possible oil-source rock correlation based on pyrolysis of asphaltenes, Scotian basin, Canada. Org Geochem 22:85-104

Obaje NG, Wehner H, Scheeder G, Abubakar MB, Jauro A (2004) Hydrocarbon prospectivity of Nigeria's inland basins: From the viewpoint of organic geochemistry and organic petrology. AAPG Bull 88(3):325-353

Papworth T (2002) Oil and gas resources of Armenia. Armenian News Network/Groong June 24

Papworth T, Aghabalyan A (2002a) Armenia's prospects - 1: Armenia void of production but not without prospects. Oil Gas J 100(32):36-39

Papworth T, Aghabalyan A (2002b) Hydrocarbon potential listed for Armenia's main basins. Oil Gas J 100(33):47-51

Peters KE (1986) Guidelines for evaluating petroleum source rock using programmed pyrolysis. AAPG Bull 70:318-329

Peters KE, Moldowan JM (1993) Interpreting Molecular Fossils in Petroleum and Ancient Sediments. The Biomarker Guide Prentice Hall, Englewood Cliffs

Peters KE, Snedden JW, Sulaeman A, Sarg JF, Enrico RJ (2000) A new geochemical sequence stratigraphic model for the Mahakam delta and Makassar slope, Kalimantan, Indonesia. AAPG Bull 84:12-44

Petersen HI (2002) A re-consideration of the "oil window" for humic coal and kerogen type III source rocks. J Petrol Geol 25:407-432

Petersen HI, Tru V, Nielsen NL, Nguyen AG, Nytoft HP (2005) Source rock properties of lacustrine Mudstones and coals (Oligocene Dong Ho Formation), onshore Song Hong Basin, Northern Vietnam. J Petrol Geol 28(1):19-38

Purvis M, Robertson AHF (2005a) Sedimentation of the NeogeneRecent Alaşehir (Gediz) continental graben system used to test alternative tectonic models for western (Aegean) Turkey. Sed Geol 173:373-408

Purvis M, Robertson AHF (2005b) Miocene sedimentary evolution of the NE-SW-trending Selendi and Gördes Basins, W Turkey: implications for extensional process. Sed Geol 174:31-62

Şahintürk Ö, Kasar S (1979) Tekman-Pasinler-Kağızman-Tuzluca Basenlerinin stratigrafik ve tektonik analizleri ile hidrokarbon olanakları [Hydrocarbon possibilities, stratigraphic and tectonic analysis of Tekman-Pasinler-Kağizman-Tuzluca basins]. TPAO Arama Grubu Rapor No. 1346, Ankara (unpublished)

Şahintürk Ö, Kasar S (1980) Tercan-Çayırlı Baseninin jeolojisi ve hidrokarbon olanakları, TPAO Arama Grubu Report number. 1446, Ankara, (unpublished)

Şahüntürk Ö, Şaroğlu F, Çaptuğ A (1998) Erzurum-Aşkale-Pasinler Horasan Baseni İ45, İ46, I47, İ48, N45, N46, N47, N48 Paftaları 1/100000' lik Yayınlanmamış Jeoloji Haritaları, Ankara [Unpublished Geological Maps of 1/100000 Sheets I445, İ46, İ47, I448, 
N45, N46, N47, N48 of Erzurum-Aşkale-Pasinler-Horasan Basin] (unpublished)

Sancay RH (2005) Palynostratigraphic and palynofacies investigation of the Oligocene-Miocene units in the Kars-Erzurum-Muş Subbasins (Eastern Anatolia). The Graduate School of Natural and Applied Sciences of METU, PhD Thesis, p 364

Şaroğlu F, Y1lmaz Y (1986) Geological evolution and basin models during the neotectonic episode in eastern Anatolia. Bull Min Res Explor Inst Turkey 107:61-83

Scheiber J, Baird G (2001) On the origin and significance of pyrite spheres in the Devonian Black Shales of North America. J Sediment Res 71(1):155-166

Şen Ş, Antoine PO, Varol B, Ayyildiz T, Sözeri K (2011) Giant rhinoceros Paraceratherium and other vertebrates from Oligocene and middle Miocene deposits of the Kağizman-Tuzluca Basin, Eastern Turkey. Naturwissenschaften 98(5):407-423

Şenalp M (1966) Erzurum-Muş bölgesi 1: 25000 ölçekli Erzurum J4732, J47-b1 ve Karaköse J48-c1, c2, c3, c4, J48-b3 paftalarının detay petrol etüdü [Detailed petroleum exploration of the Erzurum-Muş region]. MTA Report No: 4288 (unpublished), Ankara

Şenalp M (1969a) Tuzluca (Kars) havzasının 1: 25000 ölçekli detay petrol etüdü raporu [1/25000 scaled detailed petroleum exploration report of the Tuzluca (Kars) basin]: MTA Report No: 4084, Ankara (unpublished)

Şenalp M (1969b) Tuzluca-1 kuyu bitirme raporu. [Completion report of Tuzluca-1 well]. MTA Report No: 4456 (unpublished), Ankara

Şengör AMC (1987) Cross faults and differential stretching of hanging wails in regions of low angle normal faulting: examples from western Turkey. In: Coward MP, Dewey JF, Hancock PL (eds) Continental extensional tectonics. Geol Soc Lond Spec Publ 28:575-589

Shanmugam G (1985) Significance of coniferous rain forests and related oil, Gippsland Basin, Australia. Am Assoc Petrol Geol Bull 69:1241-1254

Sharkov E,. Lebedev V, Chugaev A, Zabarinskaya L, Rodnikov A, Sergeeva N, Safonova I (2015) The Caucasian-Arabian segment of the Alpine-Himalayan collisional belt: Geology, volcanism and neotectonics. Geosci Front 6:513-522

Sungurlu O (1971) İ45a, İ45b, İ46a, İ46b, İ47a, İ47b, paftalarına ait 1/50000 lik jeoloji haritaları, TPAO, Ankara (unpublished)

Tanrıverdi K (1971) Erzurum (Söylemez) yöresinin jeolojisi ve petrol olanakları [Geology and petroleum possibilities of
Erzurum (Söylemez) country]: MTA Rep., 6239, Ankara-Turkey (unpublished)

Tian J, Hao F, Zhou X, Zou H, Lan L (2014) Charging of the Penglai 9-1 oil field, Bohai Bay basin, China: functions of the delta on accumulating petroleum. Mar Pet Geol 57:603-618

Transeuro Energy Corp (2007) Armenia operations report on oil and gas information. NI December 31:51-101 13

Uğur M (2000) Kağizman-Kars-Tuzluca-Ĭgdır civarının jeolojisi ve petrol olanakları, TPAO Arama Gr. Report. No: 4137, Ankara (unpublished)

Varol B, Ayyildiz T, Karakas Z, Sözeri K (2009) Fault-induced "pullapart" terrestrial depositional model in the Igdir-Kagizman Neogene Basin, Eastern Turkey. 27th IAS Meeting Sediment. Alghero, Italy, 20-23 September. pp 35-39

Varol B, Ayyıldız T, Karakaş Z, Sözeri K (2011) Tuzluca (Iğdır) Civarındaki Neojen Birimlerinin Sedimantolojisi, KD Türkiye [Sedimentology of Neogene units of the Tuzluca (Iğdır) vicinity, NE Turkey]. TÜBİTAK Project Number 108Y026:154

Varol B, Şen Ş, Ayyıldız T, Sözeri K, Karakaş Z, Métais G (2016) Sedimentology and stratigraphy of Cenozoic deposits in the Kağizman-Tuzluca Basin, northeastern Turkey. Int J Earth Sci 105(1):107-137

Volkman JK (1986) A review of sterol biomarkers for marine and terrigenous. Org Geochem 9:83-99

Volkman JK (2003) Sterols in microorganisms. Appl Microbiol Biotechnol 60/5:495-506

Yılmaz O (2007) Kağızman (Kars)-Tuzluca (Iğdır) tuz yataklarının jeolojisi, mineralojisi ve petrografisi [Geology, mineralogy and petrography of the Kağızman (Kars)-Tuzluca (Iğdır) salt beds]. DEÜ Fen Bilimleri Enstitüsü, Ms Thesis, p 66

Yılmaz O, Şener M (1984) Erzurum-Pasinler, Erzincan-Çayırlı, KarsTuzluca, Malatya-Hacılar stratigrafik açınsama kuyularına ait örneklerin X-ışınları tekniği ile incelenmesi. Türkiye Jeol Kur Bült 2:31-40 (in Turkish with English abstract)

Publisher's Note Springer Nature remains neutral with regard to jurisdictional claims in published maps and institutional affiliations.

1 